\title{
Effect of Rhizobium inoculation and foliar spray with salicylic and ascorbic acids on growth, yield and seed quality of pea plant (Pisum sativum L.) grown on a salt affected soil, New Valley-Egypt
}

\author{
Esmat H. A. Noufal ${ }^{1}$; M. A. M. Ali ${ }^{2}$ and M. M. M. Abd El-Aal ${ }^{3}$ \\ ${ }^{1}$ Department of Soils and Water, Faculty of Agriculture, Benha University, Egypt. \\ ${ }^{2}$ Department of Horticulture, Faculty of Agriculture, Assiut University (New Valley Branch), Egypt. \\ ${ }^{3}$ Agricultural Botany Department, Faculty of Agriculture, Benha University, Egypt. \\ Corresponding author: mohamedahmedali77@aun.edu.eg
}

\begin{abstract}
A field study was carried out to investigate the effects of seed inoculation with bio-fertilizer (Rhizobium), foliar spray with antioxidants i.e., salicylic acid (SA), ascorbic acid (AA) and SA+AA at $250 \mathrm{mg} \mathrm{L}^{-1}$ of each and their interactions on growth, yield components and some seed bioconstituents of pea plant (Pisum sativum L.) cv. Master-B grown on a salt affected sandy loam soil $\left(E C=9.65 \mathrm{ds} \mathrm{m}^{-1}\right)$, New Valley-Egypt during seasons of 2015/2016 and 2016/2017 towards maximizing its productivity under salt stress conditions. Pea seeds were inoculated with Rhizobium as a bio-fertilizer source before planting. Pea seeds were inoculated at sowing with $\mathrm{N}$ fixing bacteria (Rhizobium leguminosarum). The application of antioxidants to plants was done as foliar spraying after twenty days after planting and repeated three times a ten days interval. The following data were recorded, vegetative growth parameters, root nodule characteristics, leaves photosynthetic pigments content, fresh as well as dry yield characteristics and seed chemical compositions. Inoculation significantly increased all the studied traits of pea plant grown under salinity conditions compared with un-inoculation. Foliar spraying of pea plants with antioxidants also, significantly increased all the studied aspects of pea plant, SA+AA was more efficient than spraying either solely. Inoculation seeds with Rhizobium and foliar spray of SA+AA significantly increased all the studied characteristics. SA+AA along with inoculation was more effective in increasing all the studied characteristics. Inoculation with Rhizobium along with foliar spraying with SA+AA could be recommended for growing pea under saline conditions.
\end{abstract}

Keywords: pea, Rhizobium, antioxidants, growth, yield and chemical compositions.

\section{Introduction}

Pea (Pisum sativum L.) belongs to the family Fabaceae (Leguminoseae). It is a vital legume vegetable, self-pollinated and hardy tendril climbing plant. It is a popular grain legume vegetable crop grown in Egypt and one of the major winter crops. It is the third most important legume in the world after soybean and common bean (Phaseolus vulgaris L.) (Timmerman-Vaughan et al., 2005). It is one of the important sources in human food (Hussein et al., 2006). It has high contents of amino acids, lysine and tryptophan, which relatively low in cereal grains. Pea seeds contain $21-25 \%$ protein and up to $86 \%$ of total digestible nutrients. It contains 5 to $20 \%$ less trypsin inhibitor than soybean (Kent and Endres, 2003).

Soil salinization is a major factor limiting crop cultivation and production, (Paranychianakis and Chartzoulakis, 2005; Ahmed, 2009 and Shrivastava and Kumar, 2015). Plant productivity decreases due to osmotic inhibition of water uptake by roots or due to specific ion effects which may cause direct toxicity or imbalance of plant nutritional and salinity increases $\mathrm{Na}^{+}$uptake and decreases $\mathrm{P}$ and $\mathrm{K}^{+}$uptake, (Mayak et al., 2004 and Yildirim $\boldsymbol{e t}$ al., 2006). Accumulation of excess $\mathrm{Na}^{+}$causes metabolic disturbance in plant, (Glenn et al., 1999).

Salinity stress negatively affects growth, photosynthesis, mineral nutrition, stomatal conductance, transpiration, water and ion transport and decreases sugars, amino acids and induces disorders as chlorosis, stunting leaves and impairing shoot growth, (Levy and Syvertsen, 2004). Steppuhn et al., (2001) reported that under severe salinity; neither peas nor beans produced any grain. Salinity decreases water consumption of pea and decreases photosynthetic activity, (Jamil et al., 2007).

Bio-fertilizers are preparation containing live or latent cells of efficient strains in $\mathrm{N}_{2}$ fixation or $\mathrm{P}$ and K solublization, (Vessey, 2003).

Rhizobium leguminosarum plays a principle role in $\mathrm{N}_{2}$ fixation and can increase plant growth and yield, (Sobh et al., 2000; El-Sheikh and Osman, 2002 and Tartoura, 2002). Inoculation of such strain would enhance nodulation and $\mathrm{N}_{2}$ fixing, (Zahran, 1999 and Ali et al., 2009).

Salicylic acid (SA) is a stress ameliorator (Hayat and Ahmad, 2007) and is an effective endogenous plant growth regulator, (Hayat et al., 2010). It plays physiological roles in plant including growth, thermogenesis, flower induction, nutrients uptake, ethylene biosynthesis, stomata movement, photosynthesis and enzymes activity, (Hayat and Ahmad, 2007). It is involved in nodulation and senescence, (Khan et al., 2003). It acts as regulator under salinity stress (Fahad and Bano, 2012; Iqbal et al., 2014 and Fahad et al., 2014). 
Many investigations were carried out to protect plant against adverse effects of environmental stresses (Shokr and Abdelhamid, 2009) and ascorbic acid (AA) proved important as an antioxidant and enzyme cofactor and a cell signaling modulator, (Bolkhina et al., 2003 and Wolucka et al., 2005). It plays important role in improving plant tolerance to abiotic stress, (Shalata and Neumann, 2001; Al-Hakimi and Hamada, 2001 and Athara et al., 2008). Its application to plants under salt stress increased chlorophyll content and stimulated growth and yield, (Buxton et al., 2002; Dolatabadian and Jouneghani, 2009; Gad El-Hak et al., 2012; Rady, 2013 and Mohsen et al., 2014).

The present study was conducted on pea (Pisum sativum L.) cv. Master-B to investigate the effects of seed inoculation with biofertilizer (Rhizobium), foliar applications with two antioxidants, (salicylic acid and ascorbic acid) on growth, yield and its components as well as chemical constituents of pea grown on a salt affected soil, New Valley, Egypt.

\section{Materials and Methods}

The field experiment involved bio-fertilization with or without foliar spray with antioxidants. The design was a randomized complete block, factorial (4 replicates) in a split-plot design. The main plots were assigned to bio-fertilization ( 2 treatments of none and Rhizobium inoculant). The sub-plots were assigned to foliar spray (4 treatments of no antioxidants" water spray," ascorbic acid, salicylic acid and a combination of both). The experiment was carried out at agricultural research farm of Faculty of Agriculture, Assiut University (New Valley Branch) during two successive winter seasons of 2015/2016 and 2016/2017. The soil was saline sandy loam. Table 1 shows main properties of the soil. Soil analyses were according to the methods cited by (Black, 1965 and Page et al., 1982).

Table 1. Physical and chemical properties of the experimental soil (from surface at $30 \mathrm{~cm} \mathrm{depth}$ ).

\begin{tabular}{|c|c|c|c|}
\hline Property & Value & Property & Value \\
\hline \multicolumn{2}{|c|}{ Particle size distribution } & \multicolumn{2}{|c|}{ Soluble ions $\left(\mathrm{mmol}_{\mathrm{c}} \mathrm{L}^{-1}\right)$ in Saturated soil paste extract } \\
\hline C. Sand (\%) & 5.63 & $\mathrm{HCO}_{3}^{-}$ & 2.21 \\
\hline F. Sand $(\%)$ & 76.19 & $\mathrm{CO}_{3}^{-2}$ & 0.00 \\
\hline Silt $(\%)$ & 11.15 & $\mathrm{Cl}^{-}$ & 5.79 \\
\hline Clay $(\%)$ & 7.03 & $\mathrm{SO}_{4}^{-2}$ & 1.88 \\
\hline $\begin{array}{l}\text { Soil texture (International texture } \\
\text { triangle) }\end{array}$ & Sandy loam & $\mathrm{Ca}^{+2}$ & 1.98 \\
\hline Saturation percentage $(\%)$ & 24.00 & $\mathrm{Mg}^{+2}$ & 1.18 \\
\hline Field capacity $(\%)$ & 12.00 & $\mathrm{Na}^{+}$ & 6.23 \\
\hline Wilting point $(\%)$ & 6.00 & $\mathrm{~K}^{+}$ & 0.49 \\
\hline Available water $(\%)$ & 6.00 & Available nutrients $\left(\mathrm{mg} \mathrm{kg}^{-1}\right)$ & \\
\hline $\mathrm{OM}\left(\mathrm{g} \mathrm{kg}^{-1}\right)$ & 0.49 & Available N (Kcl. Extract) & 28.3 \\
\hline $\mathrm{CaCO}_{3}\left(\mathrm{~g} \mathrm{~kg}^{-1}\right)$ & 4.98 & Available P (Na. biocarbonate extract) & 4.76 \\
\hline $\mathrm{pH}^{*}$ & 8.05 & Available $\mathrm{K}$ (Ammonium acetate extract) & 115.90 \\
\hline $\mathrm{EC}^{*}\left(\mathrm{ds} \mathrm{m}^{-1}\right)$ & 9.65 & & \\
\hline
\end{tabular}

Pea seeds were inoculated with Rhizobium before planting. The sub-plot area was $14.70 \mathrm{~m}^{2}$ and contained 6 ridges, with $3.50 \mathrm{~m}$ in length and $0.7 \mathrm{~m}$ in width. Concentration of salicylic acid as well as ascorbic acid was $250 \mathrm{mg} / \mathrm{l}$ of each.

\section{Time and method of treatments:}

\section{Bio-fertilizer (Rhizobium):}

Pea seeds were inoculated at sowing. The seeds surface were sterilized with $1 \%$ sodium hypochlorite for $20 \mathrm{~min}$ and then rinsed with water several times. The surface of disinfected seeds was coated by soaking seeds in a liquid culture medium of Rhizobium for 15 minutes using 10\% Arabic gum as adhesive, (Gabr et al., 2007). Un-inoculated seeds were soaked in distilled water for 15 minutes also. The bio-fertilizer material was used at a rate of $20 \mathrm{~g} / \mathrm{kg}$ of seeds. Rhizobial population of the inoculants used was $1.2 \times 10^{8} \mathrm{cell} / \mathrm{cm}^{3}$ obtained from the Bio-fertilizer Unit, Faculty of Agriculture, Ain Shams University, Cairo, Egypt. Inoculum was prepared in flasks by using yeast extract mannitol broth medium Singh et al., (2011) for Rhizobium. The inoculum was injected into sterile peat moss (100 $\mathrm{ml}$ inoculum per $\mathrm{kg}$ peat moss) and was incubated for $24 \mathrm{hrs}$. at $28 \pm 1^{\circ} \mathrm{C}$ before use. Seed dressing was carried out with the inoculum mixed with clay and $10 \%$ sugar solution. For the uninoculated, seeds were coated with autoclaved broth and sugar solution.

\section{Antioxidants:}

Antioxidants (ascorbic and salicylic acid) were obtained from El-Gomhoria Company for Chemicals, Egypt. The application of these solutions to plants was done as foliar spray twenty days after planting and repeated three times a ten days interval throughout the growing seasons. The rate of spray 
was $1200 \mathrm{~L}$ per hectare.

All plots were fertilized with cattle manure 70 $\mathrm{m}^{3} / \mathrm{ha}^{-1}$ and $175 \mathrm{~kg} \mathrm{~N} / \mathrm{ha}^{-1}$ as ammonium sulphate $(20.5 \% \mathrm{~N})+33 \mathrm{~kg} \mathrm{P} / \mathrm{ha}^{-1}$ as calcium superphosphate $(6.8 \% \mathrm{P})+144 \mathrm{~kg} \mathrm{~K} / \mathrm{ha}^{-1}$ as potassium sulphate $(40 \% \mathrm{~K})$ and $240 \mathrm{~kg}$ sulpher $/ \mathrm{ha}^{-1}$ divided in four equal portions and the control of insects as well as pests were done according to the instructions of down by Ministry of Agriculture. Seeds were sown on $5^{\text {th }}$ and $8^{\text {th }}$ of November for 2015 and 2016 seasons, respectively. Seeds were sown in hills 10 $\mathrm{cm}$ apart, 2 seeds per hill at $3 \mathrm{~cm}$ depth on one side of the ridge. The fresh pods were harvested on $14^{\text {th }}$ and $22^{\text {nd }}$ of January for 2016 and 2017 seasons, respectively.

1. Vegetative growth characteristics: Representative samples (ten plants per plot) were randomly taken at end of the growing season to determine the followings:

a. Shoot length $(\mathrm{cm})$ : Plants were uprooted carefully without damaging the root system. Shoot length was measured from the collar region to the tip of the plant.

b. Root length $(\mathrm{cm})$ : Roots of the uprooted plants were measured from the end region to the shoots of the plant to the tip of the roots.

c. Number of branches/plant.

d. Leaf area/plant $\left(\mathrm{cm}^{2}\right)$ was measured using the disk method and calculated according to the formula of Koller, (1972).

e. Fresh and dry weights of shoots $(\mathrm{g})$. f. Fresh and dry weights of roots $(\mathrm{g})$.

1. Chemical analysis:

Bioconstituents were carried out in the samples of seeds during 2016 and 2017 seasons.

a. Photosynthetic pigments content:

photosynthetic pioments chlorophyll A, B carotenoids extracted from fresh leaf sample at 70 days after sowing by pure acetone and the pigments were filtered, the optical density of the filtrate was determined spectrophotometrically. The pigments content (as $\mathrm{mg} / \mathrm{g}$ fresh weight) were calculated as adapted by Wettestein, (1957).

b. Seed chemical compositions: Representative seed samples at maturity stage from the second harvest were taken to determine the followings: Total nitrogen by the modified micro-Kjeldahl apparatus of Parnars and Wagner according to Jones et al., (1991) and Crude protein was calculated by multiplying $\mathrm{N}$ content by 6.25 according to A.O.A.C., (2000). Phosphorus in sulphoric-perchloric acid digest, determined by a vanadate-molybdate method, Chapman and Pratt, (1982). Potassium in acid digests, it was determined using a Perkin-elmer, Flame photometer according to Page, (1982). Total Carbohydrates was determined according to Mazumdar and Majumder, (2003). Ascorbic acid was determined by titration with 2.6 diclorophenol indophenol blue dye according to the method described by A.O.A.C., (2000). Salicylic acid was determined photometrically using spectrophotometr (Backman OU.50) described by Salinas et al., (1990) and all determinations are calculated as $\%$.

3. Nodule characteristics: Nodules of the samples were collected from roots manually, weighted and dried at $70{ }^{\circ} \mathrm{C}$ for $48 \mathrm{~h}$ to a constant weight to determine the number of root nodules/plant and the weight of nodules.

\section{Yield and its components:}

\subsection{Fresh yield characteristics:}

Fresh pods of 3 ridges in each treatment were harvested three times at 10 days interval started at the proper maturity stage (January $14^{\text {th }}$ and $22^{\text {nd }}$ in 2016 and 2017 seasons, respectively). Twenty pods were randomly taken from each plot from the second harvest and the following characteristics were calculated:

a-Fresh pod length $(\mathrm{cm})$. b-Fresh pod diameter $(\mathrm{cm})$. c- Fresh pod weight $(\mathrm{g})$.

d- Fresh seeds weight/pod (g). e- Weight of 100 fresh seeds $(\mathrm{g})$. f- Number of fresh seeds/pod. g. Fresh pod yield (ton/ha) $=3$ rows fresh pods yield $(\mathrm{kg}) \times 10000 \div 0.5$ plot area $\times 1000$.

\subsection{Dry yield characteristics}

Dry pods of the other three ridges were harvested at the end of experiment. Twenty pods were randomly taken from each plot and the following parameters were determined:

a. Average seeds weight/dry pod (g). b. Weight of 1000 dry seeds $(\mathrm{g})$.

c. Dry seed yield (ton $/$ ha) $=3$ rows dry seeds yield $(\mathrm{kg}) \times 10000 \div 0.5$ plot area $\times 1000$.

\section{Statistical analysis:}

Data were subjected to the statistical analysis of variance according to Snedecor and Cochran, (1980). The treatment means were compared using Duncan's multiple range test at probability of $5 \%$ according to Duncan, (1958).

\section{Results and Discussion}

\section{Vegetative growth characteristics:}

Results in Tables (2 and 3) show the effects of inoculation of pea seeds with Rhizobium and foliar spray with antioxidants and their interactions on vegetative growth characteristics i.e., shoot length, root length $(\mathrm{cm})$, number of branches/plant, leaf area/plant $\left(\mathrm{cm}^{2}\right)$ as well as shoot, root fresh and dry weights (g) of pea plant grown under saline conditions.

\subsection{Effect of bio-fertilizer (Rhizobium):}

As for the inoculation with Rhizobium, the obtained results reveal that inoculating pea seeds with Rhizobium significantly increased all studied vegetative growth parameters as compared with uninoculation. This pattern of response occurred in both seasons of study. However, the increase in the studied vegetative growth aspects in the second 
season was higher than that occurred in the first season and there is no significant difference between them. In this connection, (Gaballah and Gomaa, 2005) showed that Rhizobium inoculation of faba bean seeds reduced the inhibitory effect of salinity and plants were able to survive. (Gabr et al., 2007) stated that inoculation of pea seeds with Rhizobium increased plant growth characteristics i.e., plant height, number of leaves and branches, plant fresh and dry weighs. (Ullah et al., 2016) mentioned that inoculation with Rhizobium increased root length, fresh and dry weights of mung bean plant under salt stress. (Benidire et al., 2017) reported that inoculation of faba bean with the salt tolerant Rhizobium leguminosarum strains RhOF125 and RhOF34 increased plant biomass and alleviated toxic effects of salinity.

\subsection{Effect of antioxidants:}

Concerning the effect of foliar spray with the antioxidants i.e., salicylic acid (SA), ascorbic acid (AA) at $250 \mathrm{mg} / \mathrm{liter}$ of and their combination. Spraying plants with the antioxidants significantly increased all studied vegetative growth characteristics comparing with control (sprayed with water). This pattern of response occurred in both seasons of study. However, the increase in the studied vegetative growth characters in the second season was higher than that occurred in the first season and there were no significant differences between them. On the other hand, results show that spraying pea plants with the combination of salicylic and ascorbic acids gave higher values of growth traits than those obtained due to each alone. Thus, foliar spraying with the combination of salicylic and ascorbic acids was more effective in increasing vegetative growth characteristics than foliar spray of both individually. Same data also evidently confirmed the stimulatory effects of applied treatments upon dry matter production and accumulation in leaves and branches.

The effectiveness of used antioxidants in increasing growth aspects of pea plants grown under saline conditions could be supported by (Raskin, 1992) who found that SA plays an essential role in the regulation of plant growth and development. Salicylic acid is necessary for the induction of antioxidant defense and maintaining the redox state of the glutathione pool, (Borsani et al., 2001). The increasing in growth parameters of salt affected plant in response to SA might be due to the protective role of SA on membranes which increases the tolerance of plants to salt stress (Aftab et al., 2010). The SA mediated increase in growth of plants under salt stress could be to the antioxidant function and metabolic activity in plants (Gunes et al., 2007). (Palma et al., 2009) found that application with SA increased common bean dry weight and organic solutes content which indicates successful acclimatization of plants to saline conditions. (Gad
El-Hak et al., 2012) stated that foliar spray with two antioxidants of SA, AA increased pea height, dry weight and number of branches. (Sakr et al., 2013) investigated that applied AA and SA at $250 \mathrm{mg} / \mathrm{l}$ of each increased leaf area, stem and leaves dry weights of soybean under salinity stress. (Rady and Mohamed, 2015) investigated that foliar spray with SA improved shoot length, number and leaves area/plant and dry weight of common bean grown on a saline soil. (Sajid et al., 2016) showed that increases in shoot/root growth, fresh/dry mass, leaf area and stem diameter of pea grown on pots by foliar spray with SA. (Shalata and Neumann, 2001) found that SA counteracted the salt induced in growth reduction. (Gabriela $\boldsymbol{e t}$ al., 2003) reported that AA caused positive effects on physiological processes including growth regulation, differentiation and metabolism of plants as well as fundamental its role in protecting metabolic processes against toxic effects of oxygen. (Kumari et al., 2008) reported that vegetative growth of pea plant was enhanced by foliar AA. (Kamalendu and Srivastava, 2010) mentioned that pea growth increased with foliar spraying with SA. Some researchers reported that the highest plant growth was obtained from the SA foliar spray on pea (Farooq et al., 2007) and on cowpea (Dhanavel and Girija, 2009). (Salama et al., 2014) showed that foliar spray with AA mitigated the inhibitory effect of salt stress in kidney bean and induced a stimulatory effect on plant growth. (Barakat et al., 2015) assumed that spraying AA to common bean grown under reclaimed soil conditions caused positive influences on dry weight and leaf/area plant.

\subsection{Effect of the interaction between bio-fertilizer (Rhizobium) and antioxidants:}

Respect to the effect of interactions between inoculating pea seeds with Rhizobium in combination with foliar spray with antioxidants on the vegetative growth parameters of pea grown in a saline soil, results indicate that inoculation of pea seeds along with foliar spraying with antioxidants of salicylic acid (SA), ascorbic acid (AA) individually or in combination at $250 \mathrm{mg} /$ liter of each significantly increased growth parameters as compared with the sole application of Rhizobium and antioxidants. However, there was a significant interaction effect among the inoculation with Rhizobium along with foliar spray of antioxidants, where inoculation along with the combination of SA and AA gave the highest values of the vegetative growth aspects. This pattern of response occurred in both seasons of study. Such increments in growth aspects as a result of inoculation along with foliar spray of antioxidants may be attributed to the main roles of applied treatments in increasing the absorption of macro and micro nutrients from the soil and in turn affect plant vegetative growth. Such effect may be due to the role of these treatments in photosynthetic process which 
consequently effect on the amounts of photosynthetic assimilates required for cells and tissues formation and in turn effect on morphological parameters of growing plant. Increasing of formed branches on a growing plant could be reversed upon many other characteristics as number of leaves, leaf area, leaves dry weight and finally pods yield.

The effectiveness of inoculation with Rhizobium along with the foliar spray of the antioxidants in increasing growth characters of pea plant under saline conditions could be supported by (Zaki and Radwan, 2011) found that sprayed SA and AA at the rates of $150 \mathrm{mg} \mathrm{L}^{-1}$ in combination with inoculation of wheat seeds with Azotobacter chroococum obtained highest wheat growth grown on a newly reclaimed soil under saline stress.

Table 2. Vegetative growth characteristics of pea plant grown on a saline soil as affected by Rhizobium, antioxidants and their interactions during 2015/2016 and 2016/2017 growing seasons.

\begin{tabular}{|c|c|c|c|c|c|c|c|c|c|c|}
\hline \multirow[b]{2}{*}{ Treatments } & \multicolumn{5}{|c|}{$2015 / 2016$} & \multicolumn{5}{|c|}{$2016 / 2017$} \\
\hline & Control & SA & AA & $\begin{array}{c}\text { SA } \\
+ \\
\mathrm{AA}\end{array}$ & Mean & Control & SA & AA & $\begin{array}{c}\text { SA } \\
+ \\
\text { AA }\end{array}$ & Mean \\
\hline \multicolumn{11}{|c|}{ Shoot length $(\mathrm{cm})$} \\
\hline - Rhizobium & $25.40 \mathrm{f}$ & $28.90 \mathrm{e}$ & $27.80 \mathrm{e}$ & $28.90 \mathrm{e}$ & $27.75 \mathrm{~b}$ & $25.70 \mathrm{f}$ & $29.00 \mathrm{e}$ & $28.70 \mathrm{e}$ & $33.80 \mathrm{~d}$ & $29.30 \mathrm{~b}$ \\
\hline+ Rhizobium & $31.20 \mathrm{~d}$ & $35.60 \mathrm{~b}$ & $33.30 \mathrm{c}$ & $38.10 \mathrm{a}$ & $34.55 \mathrm{a}$ & $34.50 \mathrm{~cd}$ & $37.30 \mathrm{~b}$ & $36.10 \mathrm{bc}$ & $39.40 \mathrm{a}$ & $36.82 \mathrm{a}$ \\
\hline Mean & $28.30 \mathrm{c}$ & $32.25 \mathrm{a}$ & $30.55 \mathrm{~b}$ & $33.50 \mathrm{a}$ & & $30.10 \mathrm{c}$ & $33.15 \mathrm{~b}$ & $32.40 \mathrm{~b}$ & $36.60 \mathrm{a}$ & \\
\hline \multicolumn{11}{|c|}{ Root length $(\mathrm{cm})$} \\
\hline - Rhizobium & $12.48 \mathrm{f}$ & $16.29 \mathrm{e}$ & $15.18 \mathrm{e}$ & $18.27 \mathrm{~d}$ & $15.55 \mathrm{~b}$ & $13.50 \mathrm{e}$ & $17.11 \mathrm{~d}$ & $16.64 \mathrm{~d}$ & $20.28 \mathrm{c}$ & $16.88 \mathrm{~b}$ \\
\hline+ Rhizobium & $19.78 \mathrm{~cd}$ & $23.77 \mathrm{~b}$ & $21.14 \mathrm{c}$ & $26.58 \mathrm{a}$ & $22.82 \mathrm{a}$ & $21.46 \mathrm{c}$ & $25.60 \mathrm{~b}$ & $24.63 \mathrm{~b}$ & $28.64 \mathrm{a}$ & $25.08 \mathrm{a}$ \\
\hline Mean & $16.13 \mathrm{~d}$ & $20.03 \mathrm{~b}$ & $18.16 \mathrm{c}$ & $22.42 \mathrm{a}$ & & $17.48 \mathrm{c}$ & $21.35 \mathrm{~b}$ & $20.63 b$ & $24.46 \mathrm{a}$ & \\
\hline \multicolumn{11}{|c|}{ Number of branches/plant } \\
\hline - Rhizobium & $1.20 \mathrm{e}$ & $1.40 \mathrm{e}$ & $1.50 \mathrm{de}$ & $1.90 \mathrm{~cd}$ & $1.50 \mathrm{~b}$ & $1.20 \mathrm{~d}$ & $1.50 \mathrm{~d}$ & $1.60 \mathrm{~d}$ & $2.10 \mathrm{c}$ & $1.60 \mathrm{~b}$ \\
\hline+ Rhizobium & $2.10 \mathrm{bc}$ & $2.40 \mathrm{~b}$ & $2.50 \mathrm{ab}$ & $2.90 \mathrm{a}$ & $2.47 \mathrm{a}$ & $2.30 \mathrm{bc}$ & $2.40 \mathrm{bc}$ & $2.60 \mathrm{~b}$ & $3.10 \mathrm{a}$ & $2.60 \mathrm{a}$ \\
\hline Mean & $1.65 \mathrm{c}$ & $1.90 \mathrm{bc}$ & $2.00 \mathrm{~b}$ & $2.40 \mathrm{a}$ & & $1.75 \mathrm{c}$ & $1.95 \mathrm{bc}$ & $2.10 \mathrm{~b}$ & $2.60 \mathrm{a}$ & \\
\hline \multicolumn{11}{|c|}{ Leaf area/plant $\left(\mathrm{cm}^{2}\right)$} \\
\hline - Rhizobium & $22.04 \mathrm{f}$ & $26.36 \mathrm{e}$ & $27.87 \mathrm{de}$ & $29.13 \mathrm{~cd}$ & $26.35 \mathrm{~b}$ & $25.06 \mathrm{f}$ & $27.16 \mathrm{e}$ & $27.92 \mathrm{de}$ & $29.50 \mathrm{~d}$ & $27.41 \mathrm{~b}$ \\
\hline+ Rhizobium & $30.62 \mathrm{bc}$ & $32.06 \mathrm{~b}$ & $32.30 \mathrm{ab}$ & $33.85 \mathrm{a}$ & $32.21 \mathrm{a}$ & $31.34 \mathrm{c}$ & $33.65 \mathrm{~b}$ & $34.12 \mathrm{ab}$ & $35.55 \mathrm{a}$ & $33.66 \mathrm{a}$ \\
\hline Mean & $26.33 \mathrm{c}$ & $29.21 \mathrm{~b}$ & $30.08 \mathrm{~b}$ & $31.49 \mathrm{a}$ & & $28.20 \mathrm{c}$ & $30.41 \mathrm{~b}$ & $31.02 \mathrm{~b}$ & $32.53 \mathrm{a}$ & \\
\hline
\end{tabular}

Table 3. Fresh and dry weights (g) of pea plant shoot and root as affected by Rhizobium, antioxidants and their interactions during 2015/2016 and 2016/2017 growing seasons.

\begin{tabular}{|c|c|c|c|c|c|c|c|c|c|c|}
\hline \multirow[b]{2}{*}{ Treatments } & \multicolumn{5}{|c|}{$2015 / 2016$} & \multicolumn{5}{|c|}{$2016 / 2017$} \\
\hline & Control & SA & AA & $\begin{array}{c}\text { SA } \\
+ \\
\text { AA }\end{array}$ & Mean & Control & SA & AA & $\begin{array}{c}\mathrm{SA} \\
+ \\
\mathrm{AA}\end{array}$ & Mean \\
\hline \multicolumn{11}{|c|}{ Shoot fresh weight } \\
\hline - Rhizobium & $8.09 \mathrm{e}$ & $9.85 \mathrm{~d}$ & $10.65 \mathrm{~cd}$ & $11.81 \mathrm{bc}$ & $10.10 \mathrm{~b}$ & $8.49 \mathrm{e}$ & $10.55 \mathrm{~d}$ & $12.02 \mathrm{~cd}$ & $12.71 \mathrm{bc}$ & $10.94 b$ \\
\hline+ Rhizobium & $13.13 \mathrm{~b}$ & $15.02 \mathrm{a}$ & $15.38 \mathrm{a}$ & $16.58 \mathrm{a}$ & $15.03 \mathrm{a}$ & $13.99 \mathrm{~b}$ & $15.92 \mathrm{a}$ & $16.18 \mathrm{a}$ & $16.88 \mathrm{a}$ & $15.74 \mathrm{a}$ \\
\hline Mean & $10.61 \mathrm{c}$ & $12.43 \mathrm{~b}$ & $13.01 \mathrm{ab}$ & $14.19 \mathrm{a}$ & & $11.24 \mathrm{c}$ & $13.23 \mathrm{~b}$ & $14.10 \mathrm{ab}$ & $14.79 \mathrm{a}$ & \\
\hline \multicolumn{11}{|c|}{ Root fresh weight } \\
\hline - Rhizobium & $3.05 \mathrm{f}$ & $3.50 \mathrm{e}$ & $3.51 \mathrm{e}$ & $3.96 \mathrm{~d}$ & $3.50 \mathrm{~b}$ & $3.13 \mathrm{f}$ & $3.68 \mathrm{e}$ & $3.84 \mathrm{e}$ & $4.19 \mathrm{~d}$ & $3.71 \mathrm{~b}$ \\
\hline+ Rhizobium & $4.68 \mathrm{c}$ & $5.25 \mathrm{~b}$ & $5.29 \mathrm{~b}$ & $5.93 \mathrm{a}$ & $5.29 \mathrm{a}$ & $5.10 \mathrm{c}$ & $5.54 \mathrm{~b}$ & $5.58 \mathrm{~b}$ & $5.96 \mathrm{a}$ & $5.54 \mathrm{a}$ \\
\hline Mean & $3.86 \mathrm{c}$ & $4.38 \mathrm{~b}$ & $4.40 \mathrm{~b}$ & $4.95 \mathrm{a}$ & & $4.11 \mathrm{c}$ & $4.61 \mathrm{~b}$ & $4.71 \mathrm{~b}$ & $5.07 \mathrm{a}$ & \\
\hline \multicolumn{11}{|c|}{ Shoot dry weight } \\
\hline - Rhizobium & $3.14 \mathrm{f}$ & $3.30 \mathrm{f}$ & $3.52 \mathrm{e}$ & $3.79 \mathrm{~d}$ & $3.44 \mathrm{~b}$ & $3.16 \mathrm{e}$ & $3.30 \mathrm{e}$ & $4.03 \mathrm{~d}$ & $4.19 \mathrm{~cd}$ & $3.67 \mathrm{~b}$ \\
\hline+ Rhizobium & $4.05 \mathrm{c}$ & $4.35 \mathrm{~b}$ & $4.39 \mathrm{ab}$ & $4.57 \mathrm{a}$ & $4.34 \mathrm{a}$ & $4.35 \mathrm{bc}$ & $4.45 \mathrm{~b}$ & $4.69 \mathrm{a}$ & $4.87 \mathrm{a}$ & $4.59 \mathrm{a}$ \\
\hline Mean & $3.59 \mathrm{c}$ & $3.82 \mathrm{~b}$ & $3.96 \mathrm{~b}$ & $4.18 \mathrm{a}$ & & $3.75 \mathrm{c}$ & $3.87 \mathrm{c}$ & $4.36 \mathrm{~b}$ & $4.53 \mathrm{a}$ & \\
\hline \multicolumn{11}{|c|}{ Root dry weight } \\
\hline - Rhizobium & $0.94 \mathrm{~d}$ & $1.06 \mathrm{~cd}$ & $1.07 \mathrm{~cd}$ & $1.18 \mathrm{bc}$ & $1.06 \mathrm{~b}$ & $1.04 \mathrm{~d}$ & $1.09 \mathrm{~d}$ & $1.13 \mathrm{~d}$ & $1.38 \mathrm{c}$ & $1.16 \mathrm{~b}$ \\
\hline+ Rhizobium & $1.30 \mathrm{~b}$ & $1.52 \mathrm{a}$ & $1.53 \mathrm{a}$ & $1.69 \mathrm{a}$ & $1.51 \mathrm{a}$ & $1.57 \mathrm{~b}$ & $1.61 \mathrm{~b}$ & $1.64 \mathrm{ab}$ & $1.80 \mathrm{a}$ & $1.66 \mathrm{a}$ \\
\hline Mean & $1.12 \mathrm{c}$ & $1.29 \mathrm{~b}$ & $1.30 \mathrm{~b}$ & $1.43 \mathrm{a}$ & & $1.30 \mathrm{~b}$ & $1.35 \mathrm{~b}$ & $1.38 \mathrm{~b}$ & $1.59 \mathrm{a}$ & \\
\hline
\end{tabular}




\section{Photosynthetic pigments content:}

Data in Table (4) indicate the effect of inoculation pea seeds with Rhizobium and applied antioxidants i.e., SA, AA and SA+AA at $250 \mathrm{mg} / \mathrm{liter}$ of each individually or in combination treatments on the photosynthetic pigments content of chlorophyll A, B and carotenoids in pea plant leaves grown under saline conditions at 70 days after sowing during both seasons.

\subsection{Effect of bio-fertilizer (Rhizobium):}

As for the effect of Rhizobium, data in Table (4) show that inoculating seeds with Rhizobium increased the content of photosynthetic pigments of pea plants comparing with un-inoculated pea. In other words, the control treatment (un-inoculated seeds) under saline conditions gave the highest reduction in chlorophyll $\mathrm{A}, \mathrm{B}$ and carotenoids of pea plants. These results could be explained by (Gabr $\boldsymbol{e t}$ al., 2007) investigated that inoculation of pea with Rhizobium increased content of chlorophyll compared to un-inoculated. (Bambara and Ndakidemi, 2009) indicated that inoculation of Phaseolus vulgaris seeds with Rhizobium affected on chlorophyll content and the intercellular $\mathrm{CO}_{2}$ concentration compared to Rhizobium un-inoculated. (Chame et al., 2016) showed that inoculation of bean seeds with biofertilizer had a significant effect on chlorophyll index compared to non-inoculated.

\subsection{Effect of antioxidants:}

Concerning the effect of applied antioxidants of $\mathrm{SA}$, AA individually or in combination increased the content of each chlorophyll A, B and carotenoids in pea leaves at 70 days after sowing during 2016 and 2017 seasons compared to the control (sprayed with water). It could be noticed that maximum increases of these pigments content were existed with the combination between SA and AA treatment at 250 $\mathrm{mg} / \mathrm{liter}$ of each followed by SA and AA solely treatments, respectively. It was obvious that control plants were negatively affected, as they were physiologically stressed. That might be due to they were not developed any mechanism by which they could be protected against prevailing saline stress and its probable inducible oxidative one (Marschner, 1995).

In this respect, the stimulation of photosynthetic pigments formation could be attributed to the vigorous growth obtained in Tables (2 and 3 ). Increasing of chlorophylls and carotenoids content in pea leaves as affected by applied antioxidants may be due to enhancing photosynthetic efficiency and increasing dry matter production. Our results could be supported by (McKersie et al., 1996) documented that the photosynthetic apparatus is a target to reactive oxygen species. Under stress conditions, excess ROS attack lipids, protein and nucleic acids, resulted in lipid peroxidation, protein inactivation as well as DNA alteration. They also reported that plants with high level of antioxidants, whether induced a greater resistance to oxidative stress. (El(Shraiy and Hegazi, 2009) found that foliar spray with AA on pea correlated with increasing leaves chlorophyll content. (Aftab et al., 2010) reported that increasing in photosynthesis of salt affected Artemisia annua L. as a response to SA treatment may be due to the protective role of SA on membranes that may increase plants tolerance to salt stress and metabolic activity. Ascorbic acid is a major antioxidant in plant known to increase plant growth and cell cycle, through photosynthetic apparatus and plant protecting of any ROS and increasing Rubisco subunit, photosynthetic pigments thereby increasing photosynthetic rate and productivity (Chen and Gallie, 2006). (Osman et al., 2014) demonstrated that foliar application with AA increased values of chlorophyll A, B content of sunflower plant. (Salama et al., 2014) investigated that AA foliar spray not only mitigated the inhibitory effects of salt stress on kidney bean but also accompanied by increasing in photosynthetic system.

\subsection{Effect of the interaction between bio-fertilizer (Rhizobium) and antioxidants:}

As for the effect of interactions, data in Table (4) clearly indicate that the interaction effects between inoculated pea seeds with Rhizobium and applied antioxidants i.e., salicylic and ascorbic acids as well as their combination at $250 \mathrm{mg} / \mathrm{liter}$ of each treatments increased the concentration of chlorophyll A, B and carotenoids in leaves of pea plants at 70 days after sowing in 2015/2016 and 2016/2017 seasons under saline conditions. The same data cleared that the most effective treatment which led to maintained the highest concentrations of determined photosynthetic pigments was the inoculation of pea along with SA+AA followed by inoculated pea in combination with SA and Rhizobium combined with AA treatments, respectively. The same data also, evidently confirmed the stimulatory effects of different applied treatments upon dry matter production and accumulation in leaves and branches as shown in Tables ( 2 and 3 ). In general, data in Table (4) not only being a direct results for that vigorous growth obtained in Tables ( 2 and 3 ) but also could be considered an indicator for expectable high yield of pods and seeds. It was obvious from the same data the stimulatory effects of applied treatments in improving the photosynthetic pigments content and alleviated adverse effects of saline stress and its probable accompanied oxidative stress on treated pea plants may be due to their antioxidantal scavenging effects in protecting plant form degradation by toxic Reactive Oxygen Radicals which internally generated during stress, (Conklin, 2001). 
Table 4. Photosynthetic pigments content (mg/g F.W.) of pea plant leaf as affected by Rhizobium, antioxidants and their interactions during 2015/2016 and 2016/2017 growing seasons.

\begin{tabular}{|c|c|c|c|c|c|c|c|c|c|c|}
\hline \multirow{2}{*}{ Treatments } & \multicolumn{5}{|c|}{$2015 / 2016$} & \multicolumn{5}{|c|}{$2016 / 2017$} \\
\hline & Control & SA & AA & $\mathrm{SA}+\mathrm{AA}$ & Mean & Control & SA & AA & $\mathrm{SA}+\mathrm{A}$ & Mean \\
\hline \multicolumn{11}{|c|}{ Chlorophyll (A) } \\
\hline - Rhizobium & $0.53 \mathrm{f}$ & $0.81 \mathrm{de}$ & $0.74 \mathrm{e}$ & $0.87 \mathrm{~d}$ & $0.74 \mathrm{~b}$ & $0.47 \mathrm{~h}$ & $0.52 \mathrm{~g}$ & $0.58 \mathrm{f}$ & $0.67 \mathrm{e}$ & $0.56 \mathrm{~b}$ \\
\hline+ Rhizobium & $0.86 \mathrm{~d}$ & $1.03 \mathrm{c}$ & $1.18 \mathrm{~b}$ & $1.41 \mathrm{a}$ & $1.12 \mathrm{a}$ & $1.13 \mathrm{~d}$ & $1.22 \mathrm{c}$ & $1.30 \mathrm{~b}$ & $1.54 \mathrm{a}$ & $1.30 \mathrm{a}$ \\
\hline Mean & $0.69 \mathrm{c}$ & $0.92 \mathrm{~b}$ & $0.96 \mathrm{~b}$ & $1.14 \mathrm{a}$ & & $0.80 \mathrm{~d}$ & $0.87 \mathrm{c}$ & $0.94 \mathrm{~b}$ & $1.10 \mathrm{a}$ & \\
\hline \multicolumn{11}{|c|}{ Chlorophyll (B) } \\
\hline - Rhizobium & $0.12 \mathrm{~g}$ & $0.19 \mathrm{~d}$ & $0.21 \mathrm{c}$ & $0.13 \mathrm{f}$ & $0.16 \mathrm{~b}$ & $0.11 \mathrm{~h}$ & $0.19 \mathrm{e}$ & $0.14 \mathrm{f}$ & $0.12 \mathrm{~g}$ & $0.14 \mathrm{~b}$ \\
\hline+ Rhizobium & $0.18 \mathrm{e}$ & $0.28 \mathrm{~b}$ & $0.21 \mathrm{c}$ & $0.34 \mathrm{a}$ & $0.25 \mathrm{a}$ & $0.33 \mathrm{c}$ & $0.36 \mathrm{~b}$ & $0.27 \mathrm{~d}$ & $0.40 \mathrm{a}$ & $0.34 \mathrm{a}$ \\
\hline Mean & $0.15 \mathrm{c}$ & $0.23 \mathrm{a}$ & $0.21 \mathrm{~b}$ & $0.23 \mathrm{a}$ & & $0.22 \mathrm{c}$ & $0.27 \mathrm{a}$ & $0.20 \mathrm{~d}$ & $0.26 \mathrm{~b}$ & \\
\hline \multicolumn{11}{|c|}{ Carotenoids } \\
\hline - Rhizobium & $0.37 \mathrm{~h}$ & $0.42 \mathrm{~g}$ & $0.46 \mathrm{e}$ & $0.51 \mathrm{~d}$ & $0.44 \mathrm{~b}$ & $0.41 \mathrm{~g}$ & $0.57 \mathrm{~d}$ & $0.55 \mathrm{e}$ & $0.62 \mathrm{c}$ & $0.54 \mathrm{~b}$ \\
\hline+ Rhizobium & $0.45 \mathrm{f}$ & $0.73 \mathrm{a}$ & $0.58 \mathrm{~b}$ & $0.57 \mathrm{c}$ & $0.58 \mathrm{a}$ & $0.35 \mathrm{~h}$ & $0.64 \mathrm{~b}$ & $0.53 \mathrm{f}$ & $0.75 \mathrm{a}$ & $0.57 \mathrm{a}$ \\
\hline Mean & $0.41 \mathrm{~d}$ & $0.57 \mathrm{a}$ & $0.52 \mathrm{c}$ & $0.54 \mathrm{~b}$ & & $0.38 \mathrm{~d}$ & $0.60 \mathrm{~b}$ & $0.54 \mathrm{c}$ & $0.68 \mathrm{a}$ & \\
\hline
\end{tabular}

Values followed by same letters within a column not significantly differed at $5 \%$ according to Duncan's multiple range test. SA: Salicylic acid at $250 \mathrm{mg} / \mathrm{L}$. and AA: Ascorbic acid at $250 \mathrm{mg} / \mathrm{L}$.

\section{Nodule characteristics:}

As shown in Table (5) data indicate the effect of different applied treatments i.e., inoculation pea seeds with Rhizobium and foliar application with antioxidants i.e., SA, AA and SA+AA at $250 \mathrm{mg} / \mathrm{liter}$ of each individually or in combination on number of root nodules and nodule fresh as well as dry weights (g) of pea plants grown under saline conditions during both seasons.

\subsection{Effect of bio-fertilizer (Rhizobium):}

Concerning the effect of Rhizobium, the obtained results in Table (5) clearly reveal that inoculating pea seeds with Rhizobium treatment significantly increased number of root nodules, nodule fresh and nodule dry weights $(\mathrm{g})$ aspects as compared with the control (un-inoculation). This pattern of response occurred in the both seasons of study. In this respect, the obtained increases of these traits are of great interest because these data go well with the previously mentioned results i.e., estimated growth characteristics, Tables (2 and $\mathbf{3})$ as well as photosynthetic pigments content, Table (4) and will answer many questions especially about increasing yielded pods of treated pea plants. These significantly favorable effects of inoculation pea seeds with Rhizobium treatment may be explained on the basis that the beneficial effects of increasing number of root bacterial nodules and their weights on the nutrient availability, vital enzymes and hormonal stimulating effects may provide principal evident for this view.

These results are in conformity with those obtained by (Zahran, 1999) reported that salinity important stress affecting rhizobial legume symbiosis. (Slatery et al., 2001) indicated that salinity reducing population of Rhizobium in the soil and high number of naturally occurring Rhizobium population was poor in its ability to fix $\mathrm{N}$ and can compete strongly with introduced Rhizobium inoculum. Salinity inhibited nodulation and $\mathrm{N}$ fixation in Pisum sativum L. inoculated with
Rhizobium leguminosarum, this symbiosis is extremely sensitive to salt (El-Hamdaoui et al., 2003). (Gaballah and Gomaa, 2005) cleared that salinity reduced nodules formation (No. of nodules/plant and nodule dry weight) in faba bean. This effect was limited by Rhizobium inoculation. (Mishra et al., 2010) stated that highest number and dry weight of nodules per plant found by seed inoculation with Rhizobium in pea. (Aamir et al., 2013) illustrated that inoculation mung bean seeds with rhizobia increased No. of root nodules, nodule fresh and dry weights under salinity conditions. (Benidire et al., 2017) suggested that inoculation with salt tolerant Rhizobium leguminosarum increased root nodules No. in $V$. faba L. plant and seemed to protect faba bean against the toxic effects of salt stress.

\subsection{Effect of antioxidants:}

Regarding, the effect of foliar application with antioxidants, i.e., salicylic acid, ascorbic acid at 250 $\mathrm{mg} / \mathrm{liter}$ of each and their combination, the obtained results show that spraying pea plants with antioxidants significantly increased bacterial nodule characteristics comparing with control. On the other hand, results show that spraying pea plant with the combination of salicylic and ascorbic acids gave the highest values of bacterial nodule traits comparing with those obtained due to the foliar spray with salicylic or ascorbic solely. Thus, foliar spray with the combination of salicylic and ascorbic acids was more effective in increasing these aspects. Same data also evidently confirmed the stimulatory effects of applied treatments upon increment of nodulation in pea plant grown under saline conditions and seemed to protect pea plants against the toxic effects of salinity. The same data also, proved that salinity reduced pea root nodulation; this effect significantly limited by foliar application with antioxidants.

These results could be supported by (Rasmussen et al., 1991) reported that SA plays major roles at the 
early stages of Rhizobium legume symbiosis. (ElShraiy and Hegazi, 2009) indicated that application with SA on pea achieved the maximum nodules No./plant. (Ismaeil and Abd El-All, 2011) found that foliar application with salicylic and ascorbic acids increased root nodules number of faba bean plant.

\subsection{Effect of the interaction between bio-fertilizer (Rhizobium) and antioxidants:}

As for the effect of interactions, data in Table (5) clearly show that the interaction effects between inoculated pea seeds with Rhizobium and applied antioxidants i.e., SA and AA acids as well as their combination at $250 \mathrm{mg} / \mathrm{liter}$ of each treatments increased number of root nodules, nodule fresh and dry weights of pea plant during 2015/2016 and
2016/2017 seasons under saline conditions. The same data also, indicate that inoculation with Rhizobium along with foliar spray with the combination of SA and AA was the most effective treatment which gave the highest values of nodulation aspects. These significantly favorable effects of the combination between Rhizobium and antioxidants may be explained on the basis of the beneficial effects of bacteria on the nutrient availability and hormonal stimulating effects on pea plant from side and the roles of applied antioxidants to protect pea plants against the toxic effects of salinity from other side. Increment of nodulation aspects is of great interest since that could be reflected upon estimated growth characteristics and bio constituents as well as yield of pea plants grown under saline conditions.

Table 5. Number and fresh as well as dry weights ( $\mathrm{g}$ ) of pea root nodule as affected by Rhizobium, antioxidants and their interactions during 2015/2016 and 2016/2017 growing seasons.

\begin{tabular}{|c|c|c|c|c|c|c|c|c|c|c|}
\hline \multirow[b]{2}{*}{ Treatments } & \multicolumn{5}{|c|}{$2015 / 2016$} & \multicolumn{5}{|c|}{$2016 / 2017$} \\
\hline & Control & SA & AA & $\begin{array}{c}\text { SA } \\
+ \\
\text { AA }\end{array}$ & Mean & Control & SA & AA & $\begin{array}{c}\text { SA } \\
+ \\
\text { AA }\end{array}$ & Mean \\
\hline \multicolumn{11}{|c|}{ Number of root nodules/plant } \\
\hline - Rhizobium & $2.20 \mathrm{~d}$ & $3.40 \mathrm{c}$ & $3.30 \mathrm{c}$ & $3.70 \mathrm{c}$ & $3.15 \mathrm{~b}$ & $2.50 \mathrm{e}$ & $3.60 \mathrm{~d}$ & $3.60 \mathrm{~d}$ & $4.20 \mathrm{~d}$ & $3.47 \mathrm{~b}$ \\
\hline+ Rhizobium & $9.90 \mathrm{~b}$ & $11.80 \mathrm{a}$ & $11.60 \mathrm{a}$ & $12.20 \mathrm{a}$ & $11.37 \mathrm{a}$ & $10.90 \mathrm{c}$ & $14.20 \mathrm{ab}$ & $13.50 \mathrm{~b}$ & $14.70 \mathrm{a}$ & $13.32 \mathrm{a}$ \\
\hline Mean & $6.05 \mathrm{~b}$ & $7.60 \mathrm{a}$ & $7.45 \mathrm{a}$ & $7.95 \mathrm{a}$ & & $6.70 \mathrm{c}$ & $8.90 \mathrm{ab}$ & $8.55 \mathrm{~b}$ & $9.45 \mathrm{a}$ & \\
\hline \multicolumn{11}{|c|}{ Nodule fresh weight } \\
\hline - Rhizobium & $0.182 \mathrm{f}$ & $0.204 \mathrm{e}$ & $0.202 \mathrm{e}$ & $0.250 \mathrm{~d}$ & $0.209 \mathrm{~b}$ & $0.198 \mathrm{~g}$ & $0.257 \mathrm{e}$ & $0.236 \mathrm{f}$ & $0.325 \mathrm{~d}$ & $0.254 \mathrm{~b}$ \\
\hline+ Rhizobium & $0.356 \mathrm{c}$ & $0.409 \mathrm{a}$ & $0.382 \mathrm{~b}$ & $0.409 \mathrm{a}$ & $0.389 \mathrm{a}$ & $0.388 \mathrm{c}$ & $0.492 \mathrm{a}$ & $0.445 \mathrm{~b}$ & $0.504 \mathrm{a}$ & $0.457 \mathrm{a}$ \\
\hline Mean & $0.269 \mathrm{~d}$ & $0.306 \mathrm{~b}$ & $0.292 \mathrm{c}$ & $0.329 \mathrm{a}$ & & $0.293 \mathrm{~d}$ & $0.374 \mathrm{~b}$ & $0.340 \mathrm{c}$ & $0.414 \mathrm{a}$ & \\
\hline \multicolumn{11}{|c|}{ Nodule dry weight } \\
\hline - Rhizobium & $0.016 \mathrm{e}$ & $0.019 \mathrm{~d}$ & $0.017 \mathrm{e}$ & $0.022 \mathrm{c}$ & $0.018 \mathrm{~b}$ & $0.016 \mathrm{f}$ & $0.020 \mathrm{e}$ & $0.019 \mathrm{e}$ & $0.027 \mathrm{~d}$ & $0.021 \mathrm{~b}$ \\
\hline+ Rhizobium & $0.028 \mathrm{~b}$ & $0.034 \mathrm{a}$ & $0.034 \mathrm{a}$ & $0.035 \mathrm{a}$ & $0.033 \mathrm{a}$ & $0.033 \mathrm{c}$ & $0.040 \mathrm{a}$ & $0.038 \mathrm{~b}$ & $0.040 \mathrm{a}$ & $0.038 \mathrm{a}$ \\
\hline Mean & $0.022 \mathrm{c}$ & $0.026 \mathrm{~b}$ & $0.025 \mathrm{~b}$ & $0.028 \mathrm{a}$ & & $0.025 \mathrm{c}$ & $0.030 \mathrm{~b}$ & $0.029 \mathrm{~b}$ & $0.034 \mathrm{a}$ & \\
\hline
\end{tabular}

Values followed by same letters within a column not significantly differed at 5\% according to Duncan's multiple range test. SA: Salicylic acid at $250 \mathrm{mg} / \mathrm{L}$. and AA: Ascorbic acid at $250 \mathrm{mg} / \mathrm{L}$.

\section{Yield and its components:}

As for the effect of different applied treatments, data in Tables (6 and 7) clearly indicate that each of inoculation of pea seeds with Rhizobium, foliar application of antioxidants and their interaction treatments had significant effects on studied fresh as well as dry yield characteristics i.e., pod length, pod diameter $(\mathrm{cm})$, fresh pod weight, fresh seeds weight, weight of 100 fresh seeds $(\mathrm{g})$, number of fresh seeds/pod, seeds weight/dry pod, weight of 1000 dry seeds $(\mathrm{g})$, fresh pod yield and dry seed yield ton/ha of pea plants grown under saline conditions during both seasons.

\subsection{Effect of bio-fertilizer (Rhizobium):}

Regarding, the effect of inoculation, the obtained results show that inoculating pea seeds with Rhizobium significantly increased fresh as well as dry yield characteristics of pea plants as compared with un-inoculation in both seasons.

These results are in agreement with those of (Shafeek et al., 2004) on bean and (Abou El-
Salehein et al., 2005) on pea observed that inoculation with Rhizobium improved pod characteristics. (Gaballah and Gomaa, 2005) reported that used Rhizobium inoculation on faba bean seeds obtained yield increasing. (Ahmed $\boldsymbol{e t}$ al., 2007) found that used inoculation with Rhizobium on pea obtained increases in number of pods/plant, pod length/plant, number of seeds/pod, 1000 fresh and mature seed weights, fresh pod and mature seed yield. (El Sayed et al., 2012) reported that pea seeds inoculated with Rhizobium increased yield traits i.e., pod length, pod weight, number of fresh seeds/pod, weight of 100 fresh seed and seed index.

These present results show that bacterial inoculants, favored the following beneficial effects, $\mathrm{N}_{2}$ fixation, acquisition of $\mathrm{P}$, increasing availability of nutrients and producing adequate amounts of Auxins and Cytokinins which affect growth, morphological and physiological aspects of root, (Martin et al., 1989 and Jagnow et al., 1991). 


\subsection{Effect of antioxidants:}

As for the effect of antioxidants, the recorded data reveal that spray pea plants with SA, AA and their combination significantly increased fresh and dry yield components of pea plant as compared with non-sprayed. There was no significant difference between $\mathrm{SA}$ and $\mathrm{AA}$ in increasing yield aspects except fresh pod weight. The highest yield characteristic values were obtained by foliar spray with the combination of SA and AA. There was a significant difference between the effect of foliar spray with the combination of SA and AA in increasing yield traits and foliar spray with each of SA and AA individually, except weight of 100 fresh seeds. Consequently, foliar spray with the combination of salicylic and ascorbic acids was more effective than foliar spray of both individually. Such increments in yield aspects as a result of using tested antioxidants may be due to the main role of antioxidants on enzymatic reactions in plant metabolism and its role in catching and binding as well as scavenging of ROS which affect on plant metabolism and consequently increased plant yield. The increasing in plant yield traits may be attributed to increasing of photosynthetic pigments, absorption of nutrients and their effects on different physiological and chemical reactions in plant which positively effect on plant yield (Marschner, 1995).

The effectiveness of studied antioxidants in increasing yield characteristics of pea plant grown under saline conditions could be supported by (Ghulam, 2007) reported that foliar spray pea with SA increased yield aspects. (El-Hendaway $\boldsymbol{e t}$ al., 2011) concluded that faba bean yield increased with foliar spray of SA. (Radi et al., 2001 and Ebrahim, 2005) reported that AA increased dry matter yield of salt stressed bean. (Helal et al., 2005) on pea plant concluded that spray with AA increased yield. This may be due to increases in endogenous promoter phytohormones, in addition stimulating plant growth and $\mathrm{CO}_{2}$ as well as microbial activity (Abd ElHalim, 1995). These results confirm the positive effects of spray with AA on influencing several physiological process as stimulating cell division and several enzymes activities (Abd-El-Hamed $\boldsymbol{e t}$ al., 2004; Irfan et al., 2006 and Zewail, 2007). AA inhibits stress induced leakage of essential electrolytes following peroxidative damage for plasma membrane (McKersie et al., 1999). The effect of AA in mitigating the adverse effects of salt stress may be due to the activation of enzymatic reactions. (El-Shraiy and Hegazi, 2009) reported that obtained increases in 1000 seed weight and pod yield of pea by foliar spray with SA. (Chame et al., 2016) stated that sprayed beans with $S A$ increases 100 seeds weight and grain yield under salinity. The effect of foliar spray with antioxidants on increasing fresh pod yield of pea could be a result to the effect on improving plant growth (Gad El-Hak et al., 2012). These results are in agreement with (Gahalain et al., 1999; Alqurainy, 2007 and Yadav et al., 2008) on pea and (Sultana et al., 2009) on faba bean. (Khafaga et al., 2014) showed that foliar application of AA increased faba bean productivity.

\subsection{Effect of the interaction between bio-fertilizer (Rhizobium) and antioxidants:}

With regard to the effect of inoculation along with foliar spray of antioxidants on fresh and dry yield characteristics of pea plant grown in a saline soil, results indicate that inoculation of pea seeds with Rhizobium along with foliar spray with antioxidants significantly increased yield aspects as compared with the sole application of both. There was a significant difference between the combination of SA+AA foliar spray along with inoculation and the effect of foliar spray of SA or AA along with inoculation. The highest yield characteristics were obtained due to spray SA+AA along with inoculation. The effectiveness of inoculation along with foliar spray of antioxidants in increasing yield aspects could be arranged as Rhizobium+combination of SA+AA was the most superior treatment followed by the combination of Rhizobium and SA then the combination of Rhizobium and AA treatments, respectively.

It was obvious from the data that control plant was strongly stressed. Incongruity, the different applied treatments increased plant yield aspects as a direct result for the simulative effect of these treatments, that actively enhanced the internal metabolically protective status by their direct scavenging functions against the toxic free radicals (induced by saline stress) or due to their promotional effect on synthesis of natural protective antioxidants, Table (9) i.e., phenols, sugars, carotenoids and so on as well as they induce an potent biosynthesis case due to the higher photosynthetic pigments content as shown in Table (4), protection of chlorophyll and chloroplasts against stress degradable effects from a side as well as increasing the absorption root surface for water and nutrients which consequently affect positively on plant growth, Tables ( 2 and 3 ) from other side, there by higher carbohydrates accumulation and content as well as higher minerals $\mathrm{N}, \mathrm{P}$ and $\mathrm{K}$ content, Table (8) which finally resulting in increasing plant yield, Tables (6 and 7). The strong positive correlations of such constituent vs. seeds yield confirm and coincide such functions of antioxidants under saline stress. (Chame et al., 2016) reported that inoculating bean seeds with biofertilizer and using SA alleviated the effects of salinity on yield. 
Table 6. Yield characteristics of pea plant as affected by Rhizobium, antioxidants and their interactions during 2015/2016 and 2016/2017 growing seasons.

\begin{tabular}{|c|c|c|c|c|c|c|c|c|c|c|}
\hline \multirow[b]{2}{*}{ Treatments } & \multicolumn{5}{|c|}{$2015 / 2016$} & \multicolumn{5}{|c|}{$2016 / 2017$} \\
\hline & Control & SA & AA & $\begin{array}{c}\text { SA } \\
+ \\
\text { AA }\end{array}$ & Mean & Control & SA & AA & $\begin{array}{c}\text { SA } \\
+ \\
\text { AA }\end{array}$ & Mean \\
\hline \multicolumn{11}{|c|}{ Fresh pod length $(\mathrm{cm})$} \\
\hline - Rhizobium & $7.35 \mathrm{e}$ & $7.59 \mathrm{~d}$ & $7.53 \mathrm{de}$ & $7.87 \mathrm{c}$ & $7.58 \mathrm{~b}$ & $7.44 \mathrm{f}$ & $7.68 \mathrm{ef}$ & $7.75 \mathrm{e}$ & $8.06 \mathrm{~d}$ & $7.73 \mathrm{~b}$ \\
\hline+ Rhizobium & $8.07 \mathrm{c}$ & $8.55 \mathrm{~b}$ & $8.33 \mathrm{~b}$ & $8.88 \mathrm{a}$ & $8.45 \mathrm{a}$ & $8.26 \mathrm{~cd}$ & $8.63 \mathrm{ab}$ & $8.48 \mathrm{bc}$ & $8.91 \mathrm{a}$ & $8.57 \mathrm{a}$ \\
\hline Mean & $7.71 \mathrm{c}$ & $8.07 \mathrm{~b}$ & $7.93 \mathrm{~b}$ & $8.37 \mathrm{a}$ & & $7.85 \mathrm{c}$ & $8.15 \mathrm{~b}$ & $8.11 \mathrm{~b}$ & $8.48 \mathrm{a}$ & \\
\hline \multicolumn{11}{|c|}{ Fresh pod diameter $(\mathrm{cm})$} \\
\hline - Rhizobium & $1.02 \mathrm{~d}$ & $1.05 \mathrm{~cd}$ & $1.05 \mathrm{~cd}$ & $1.09 \mathrm{bc}$ & $1.05 \mathrm{~b}$ & $1.02 \mathrm{e}$ & $1.06 \mathrm{de}$ & $1.07 \mathrm{de}$ & $1.09 \mathrm{~d}$ & $1.06 \mathrm{~b}$ \\
\hline+ Rhizobium & $1.10 \mathrm{bc}$ & $1.14 \mathrm{~b}$ & $1.13 \mathrm{~b}$ & $1.21 \mathrm{a}$ & $1.14 \mathrm{a}$ & $1.11 \mathrm{~cd}$ & $1.15 \mathrm{bc}$ & $1.17 \mathrm{~b}$ & $1.24 \mathrm{a}$ & $1.16 \mathrm{a}$ \\
\hline Mean & $1.06 \mathrm{~b}$ & $1.09 \mathrm{~b}$ & $1.09 \mathrm{~b}$ & $1.15 \mathrm{a}$ & & $1.06 \mathrm{c}$ & $1.10 \mathrm{~b}$ & $1.12 \mathrm{~b}$ & $1.16 \mathrm{a}$ & \\
\hline \multicolumn{11}{|c|}{ Fresh pod weight $(\mathrm{g})$} \\
\hline - Rhizobium & $5.90 \mathrm{e}$ & $6.52 \mathrm{~d}$ & $6.17 \mathrm{e}$ & $6.53 \mathrm{~d}$ & $6.28 \mathrm{~b}$ & $6.21 \mathrm{e}$ & $6.58 \mathrm{~d}$ & $6.55 \mathrm{~d}$ & $6.76 \mathrm{~cd}$ & $6.53 \mathrm{~b}$ \\
\hline+ Rhizobium & $6.68 \mathrm{~cd}$ & $7.34 \mathrm{~b}$ & $6.87 \mathrm{c}$ & $7.65 \mathrm{a}$ & $7.13 \mathrm{a}$ & $6.97 \mathrm{bc}$ & $7.56 \mathrm{a}$ & $7.05 \mathrm{~b}$ & $7.77 \mathrm{a}$ & $7.34 \mathrm{a}$ \\
\hline Mean & $6.29 \mathrm{c}$ & $6.93 \mathrm{a}$ & $6.52 \mathrm{~b}$ & $7.09 \mathrm{a}$ & & $6.59 \mathrm{c}$ & $7.07 \mathrm{a}$ & $6.80 \mathrm{~b}$ & $7.26 \mathrm{a}$ & \\
\hline \multicolumn{11}{|c|}{ Fresh seeds weight/pod (g) } \\
\hline - Rhizobium & $2.29 \mathrm{f}$ & $2.64 \mathrm{de}$ & $2.55 \mathrm{e}$ & $2.81 \mathrm{~d}$ & $2.57 \mathrm{~b}$ & $2.30 \mathrm{f}$ & $2.65 \mathrm{e}$ & $2.62 \mathrm{e}$ & $2.87 \mathrm{~d}$ & $2.61 \mathrm{~b}$ \\
\hline+ Rhizobium & $3.05 \mathrm{c}$ & $3.49 \mathrm{~b}$ & $3.37 \mathrm{~b}$ & $3.79 \mathrm{a}$ & $3.42 \mathrm{a}$ & $3.06 \mathrm{c}$ & $3.56 \mathrm{~b}$ & $3.45 \mathrm{~b}$ & $3.89 \mathrm{a}$ & $3.49 \mathrm{a}$ \\
\hline Mean & $2.67 \mathrm{c}$ & $3.06 \mathrm{~b}$ & $2.96 \mathrm{~b}$ & $3.30 \mathrm{a}$ & & $2.68 \mathrm{c}$ & $3.11 \mathrm{~b}$ & $3.03 \mathrm{~b}$ & $3.38 \mathrm{a}$ & \\
\hline \multicolumn{11}{|c|}{ Weight of 100 fresh seeds $(\mathrm{g})$} \\
\hline - Rhizobium & $38.26 \mathrm{~d}$ & $40.85 \mathrm{~cd}$ & $40.67 \mathrm{~cd}$ & $41.52 \mathrm{~cd}$ & $40.33 b$ & $38.41 \mathrm{e}$ & $41.10 \mathrm{de}$ & $41.08 \mathrm{de}$ & $41.82 \mathrm{~d}$ & $40.60 \mathrm{~b}$ \\
\hline+ Rhizobium & $42.48 \mathrm{bc}$ & $46.12 \mathrm{a}$ & $45.32 \mathrm{ab}$ & $48.65 \mathrm{a}$ & $45.64 \mathrm{a}$ & $42.66 \mathrm{~cd}$ & $46.47 \mathrm{ab}$ & $45.64 \mathrm{bc}$ & $49.29 \mathrm{a}$ & $46.01 \mathrm{a}$ \\
\hline Mean & $40.37 \mathrm{~b}$ & $43.48 \mathrm{a}$ & $43.00 \mathrm{a}$ & $45.09 \mathrm{a}$ & & $40.53 \mathrm{~b}$ & $43.79 \mathrm{a}$ & $43.36 \mathrm{a}$ & $45.55 \mathrm{a}$ & \\
\hline
\end{tabular}

Values followed by same letters within a column not significantly differed at $5 \%$ according to Duncan's multiple range test. SA: Salicylic acid at $250 \mathrm{mg} / \mathrm{L}$. and AA: Ascorbic acid at $250 \mathrm{mg} / \mathrm{L}$.

Table 7. Yield characteristics of pea plant as affected by Rhizobium, antioxidants and their interactions during $2015 / 2016$ and 2016/2017 growing seasons.

\begin{tabular}{|c|c|c|c|c|c|c|c|c|c|c|}
\hline \multirow[b]{2}{*}{ Treatments } & \multicolumn{5}{|c|}{$2015 / 2016$} & \multicolumn{5}{|c|}{$2016 / 2017$} \\
\hline & Control & SA & AA & $\begin{array}{c}\text { SA } \\
+ \\
\text { AA }\end{array}$ & Mean & Control & SA & AA & $\begin{array}{c}\text { SA } \\
+ \\
\text { AA }\end{array}$ & Mean \\
\hline \multicolumn{11}{|c|}{ Number of fresh seeds/pod } \\
\hline - Rhizobium & $6.00 \mathrm{f}$ & $6.50 \mathrm{de}$ & $6.30 \mathrm{ef}$ & $6.80 \mathrm{~cd}$ & $6.40 \mathrm{~b}$ & $6.00 \mathrm{~d}$ & $6.50 \mathrm{c}$ & $6.40 \mathrm{c}$ & $6.90 \mathrm{~b}$ & $6.45 b$ \\
\hline+ Rhizobium & $7.20 \mathrm{bc}$ & $7.60 \mathrm{ab}$ & $7.50 \mathrm{ab}$ & $7.80 \mathrm{a}$ & $7.52 \mathrm{a}$ & $7.20 \mathrm{~b}$ & $7.70 \mathrm{a}$ & $7.60 \mathrm{a}$ & $7.90 \mathrm{a}$ & $7.60 \mathrm{a}$ \\
\hline Mean & $6.60 \mathrm{c}$ & $7.05 \mathrm{ab}$ & $6.90 \mathrm{~b}$ & $7.30 \mathrm{a}$ & & $6.60 \mathrm{c}$ & $7.10 \mathrm{~b}$ & $7.00 \mathrm{~b}$ & $7.40 \mathrm{a}$ & \\
\hline \multicolumn{11}{|c|}{ seeds weight/dry pod (g) } \\
\hline - Rhizobium & $0.36 \mathrm{f}$ & $0.62 \mathrm{e}$ & $0.58 \mathrm{e}$ & $0.75 \mathrm{~d}$ & $0.58 \mathrm{~b}$ & $0.39 \mathrm{f}$ & $0.77 \mathrm{e}$ & $0.71 \mathrm{e}$ & $0.89 \mathrm{~d}$ & $0.69 \mathrm{~b}$ \\
\hline+ Rhizobium & $1.09 \mathrm{c}$ & $1.38 \mathrm{~b}$ & $1.33 \mathrm{~b}$ & $1.67 \mathrm{a}$ & $1.37 \mathrm{a}$ & $1.13 \mathrm{c}$ & $1.46 \mathrm{~b}$ & $1.38 \mathrm{~b}$ & $1.71 \mathrm{a}$ & $1.42 \mathrm{a}$ \\
\hline Mean & $0.72 \mathrm{c}$ & $1.00 \mathrm{~b}$ & $0.96 \mathrm{~b}$ & $1.21 \mathrm{a}$ & & $0.76 \mathrm{c}$ & $1.12 \mathrm{~b}$ & $1.04 \mathrm{~b}$ & $1.30 \mathrm{a}$ & \\
\hline \multicolumn{11}{|c|}{ Weight of 1000 dry seeds (g) } \\
\hline - Rhizobium & $60.16 \mathrm{f}$ & $96.14 \mathrm{e}$ & $93.19 \mathrm{e}$ & $111.40 \mathrm{~d}$ & $90.22 \mathrm{~b}$ & $65.83 \mathrm{f}$ & $119.85 \mathrm{de}$ & $111.30 \mathrm{e}$ & $130.59 \mathrm{~d}$ & $106.89 \mathrm{~b}$ \\
\hline+ Rhizobium & $152.41 \mathrm{c}$ & $182.08 \mathrm{~b}$ & $179.25 \mathrm{~b}$ & $215.00 \mathrm{a}$ & $182.18 \mathrm{a}$ & $157.96 \mathrm{c}$ & $191.73 \mathrm{~b}$ & $182.64 \mathrm{~b}$ & $217.00 \mathrm{a}$ & $187.33 \mathrm{a}$ \\
\hline Mean & $106.28 \mathrm{c}$ & $139.11 \mathrm{~b}$ & $136.22 \mathrm{~b}$ & $163.20 \mathrm{a}$ & & $111.89 \mathrm{c}$ & $155.79 \mathrm{~b}$ & $146.97 \mathrm{~b}$ & $173.79 \mathrm{a}$ & \\
\hline \multicolumn{11}{|c|}{ Fresh pod yield (ton/ha) } \\
\hline - Rhizobium & $3.20 \mathrm{f}$ & $4.67 \mathrm{de}$ & $4.21 \mathrm{e}$ & $5.30 \mathrm{~d}$ & $4.35 \mathrm{~b}$ & $3.92 \mathrm{f}$ & $4.83 \mathrm{e}$ & $4.68 \mathrm{e}$ & $5.53 \mathrm{~d}$ & $4.74 \mathrm{~b}$ \\
\hline+ Rhizobium & $6.25 \mathrm{c}$ & $7.87 \mathrm{ab}$ & $7.21 \mathrm{~b}$ & $8.38 \mathrm{a}$ & $7.43 \mathrm{a}$ & $6.39 \mathrm{c}$ & $7.93 \mathrm{~b}$ & $7.73 \mathrm{~b}$ & $8.56 \mathrm{a}$ & $7.65 \mathrm{a}$ \\
\hline Mean & $4.73 \mathrm{~d}$ & $6.27 \mathrm{~b}$ & $5.71 \mathrm{c}$ & $6.84 \mathrm{a}$ & & $5.15 \mathrm{c}$ & $6.38 \mathrm{~b}$ & $6.20 \mathrm{~b}$ & $7.05 \mathrm{a}$ & \\
\hline \multicolumn{11}{|c|}{ Dry seed yield (ton/ha) } \\
\hline - Rhizobium & $1.02 \mathrm{f}$ & $1.25 \mathrm{e}$ & $1.17 \mathrm{e}$ & $1.43 \mathrm{~d}$ & $1.22 \mathrm{~b}$ & $1.15 \mathrm{f}$ & $1.44 \mathrm{~d}$ & $1.32 \mathrm{e}$ & $1.45 \mathrm{~d}$ & $1.34 \mathrm{~b}$ \\
\hline+ Rhizobium & $1.52 \mathrm{c}$ & $1.65 \mathrm{~b}$ & $1.60 \mathrm{~b}$ & $1.75 \mathrm{a}$ & $1.63 \mathrm{a}$ & $1.55 \mathrm{c}$ & $1.73 \mathrm{ab}$ & $1.66 \mathrm{~b}$ & $1.78 \mathrm{a}$ & $1.68 \mathrm{a}$ \\
\hline Mean & $1.27 \mathrm{~d}$ & $1.45 \mathrm{~b}$ & $1.39 \mathrm{c}$ & $1.59 \mathrm{a}$ & & $1.35 \mathrm{c}$ & $1.58 \mathrm{a}$ & $1.49 \mathrm{~b}$ & $1.61 \mathrm{a}$ & \\
\hline
\end{tabular}

Values followed by same letters within a column not significantly differed at $5 \%$ according to Duncan's multiple range test. SA: Salicylic acid at $250 \mathrm{mg} / \mathrm{L}$. and AA: Ascorbic acid at $250 \mathrm{mg} / \mathrm{L}$. 


\section{Seed chemical compositions:}

Data in Tables (8 and 9) clearly show the effect of the inoculation of pea seeds with Rhizobium and foliar spray of pea plant with antioxidants as well as their combinations on some bioconstituents of $\mathrm{N}, \mathrm{P}$, $\mathrm{K}$, crude protein, total carbohydrates, ascorbic and salicylic acids \% during both seasons.

\subsection{Effect of bio-fertilizer (Rhizobium):}

Concerning the effect of inoculation of pea seeds with Rhizobium, it could be noticed that inoculating significantly increased chemical compositions of pea seeds as compared with un-inoculation in both seasons of study.

Similar results were reported by (Marschner, 1995) indicated that increasing seed bioconstituents is a result of $\mathrm{N}$ fixation by Rhizobium from the atmospheric $\mathrm{N}$ in root media, since more than $90 \%$ of fixed $\mathrm{N}$ translocate from bacteria to the different organs. (Ahmed et al., 2007) stated that inoculation with Rhizobium performed best recording in protein pea seed content. (El Sayed et al., 2012) showed that pea seeds inoculated with Rhizobium increased N, P, $\mathrm{K}$, carbohydrates and protein of fresh seeds. (Aamir et al., 2013) observed that inoculation of mung bean with Rhizobium increased N, P, K and protein content in seeds under salinity conditions.

\subsection{Effect of antioxidants:}

Regarding to the effect of foliar spray with antioxidants i.e., SA and AA as well as their combination, the obtained results show that spray pea plant with antioxidants significantly increased $\mathrm{N}, \mathrm{P}$, $\mathrm{K}$, crude protein, total carbohydrates, ascorbic and salicylic acids \% of pea seeds as compared with untreated plant.

In other words, different applied treatments individually or in combination increased determined biochemical compositions of pea seeds grown under saline conditions. In this respect, combination between SA and AA gave the highest values followed by SA and AA solely treatment, respectively when compared with control.

These results are in harmony with (Raskin, 1992) documented that phenolic compounds exert their influence on physiological and biochemical processes including photosynthesis, ions uptake, enzyme activities and so on. SA is a natural compound may be function as a plant growth regulator (Arberg, 1981). Not only SA could be recommended to improve plant growth and productivity but also to induce plant resistance against the biotic and abiotic stresses as well, (Raskin, 1995). (Haroun et al., 1998) reported that SA increased total carbohydrates content in lupine seed. (Sarang et al., 2003) showed that $\mathrm{N}$ and protein contents increased in Phaseolus vulgaris with foliar spray of SA. SA increases uptake of potassium under salinity stress, potassium being essential to protein synthesis (Kim et al., 2005). Salicylic acid enhanced antioxidant system and reduces the destructive effects of ROS (Ghorbani et al., 2004).
(Trachevsky et al., 2011) mentioned that foliar spray with SA on pea produced high protein content and P $\%$. (Hadi et al., 2014) showed that SA was the most effective treatment on protein content of white bean seed and reduced adverse effects of salinity. (Gad El-Hak et al., 2012) reported that foliar spray with AA affected N, protein and $\mathrm{P}$ in pea seeds. (Talaat, 2003) stated that nitrate accumulation by foliar spray with AA may be due to the positive effect of AA on root growth which accordingly increasing absorption of nitrate. (El-Bassiouny et al., 2005) indicated that foliar spray with AA on faba bean increased total carbohydrates, protein, $\mathrm{K}, \mathrm{P}$ and $\mathrm{Ca}$ contents in seeds. (Khafaga et al., 2014) found that AA foliar application increased $\mathrm{N}, \mathrm{P}$ and $\mathrm{K}$ contents in seeds of faba bean.

\subsection{Effect of the interaction between bio-fertilizer} (Rhizobium) and antioxidants:

As for the effect of inoculating pea seeds with Rhizobium along with foliar spray with antioxidants on seeds bioconstituents i.e., N, P, K, crude protein, total carbohydrates, ascorbic and salicylic acids \%, results indicate that inoculation along with foliar spray with combination of SA and AA at 250 $\mathrm{mg} / \mathrm{liter}$ of each was the most effective treatment which gave the highest values followed by Rhizobium+SA and Rhizobium+AA treatments, respectively during both seasons. In this respect, increasing of pea seeds biochemical compositions with different applied treatments consider as a direct result of increasing photosynthesis rate and efficiency. That was preceded with large photosynthetic area, Table (2) as well as high concentration of photosynthetic pigments, Table (4). Such promotional effect of applied antioxidants could be due to their similar effects on leaves, surfaces of photoassimilation. Thereby, the capacity of $\mathrm{Co}_{2}$ fixation and carbohydrates synthesis. Treated plants with these treatments were of higher carbohydrates and sugars concentrations might be exported sufficient sugars at early stage, those essentially required for protective effect on the most sensitive reproductive organs i.e., pollen grains and ovules and their viability and in turn, increasing of the efficiency of fertilization process as well as pods setting activities. Such accumulation in osmolytes is necessary for the maintenance of plants under saline stress due to its important roles in osmoregulation and osmotic adjustment, the disturbance in plant osmotic under stress conditions could attributed to the imbalance of most metabolic processes, i.e., photosynthesis, respiration, transpiration, enzyme activities and protein synthesis. Generally, it could be concluded that different applied treatments were mostly effective, which induced an active metabolically case and the most effective internal defensive antioxidantal mechanism i.e., carotenoids, phenols, sugars, protein and so on. At the same time, this was accompanied with good morphological, minerals status and agronomical performances. The 
results are coincided with those of (Chame et al., 2016) indicated that inoculation bean seeds with biofertilizer and using SA reduced the effect of salinity on seed protein content.

Table 8. N, P, K and crude protein \% of pea seeds as affected by Rhizobium, antioxidants and their interactions during 2015/2016 and 2016/2017 growing seasons.

\begin{tabular}{|c|c|c|c|c|c|c|c|c|c|c|}
\hline \multirow[b]{2}{*}{ Treatments } & \multicolumn{5}{|c|}{$2015 / 2016$} & \multicolumn{5}{|c|}{$2016 / 2017$} \\
\hline & Control & SA & AA & $\begin{array}{c}\text { SA } \\
+ \\
\text { AA } \\
\end{array}$ & Mean & Control & SA & AA & $\begin{array}{c}\text { SA } \\
+ \\
\text { AA } \\
\end{array}$ & Mean \\
\hline \multicolumn{11}{|c|}{ Nitrogen } \\
\hline - Rhizobium & $2.73 \mathrm{e}$ & $3.00 \mathrm{~d}$ & $3.23 \mathrm{~cd}$ & $3.22 \mathrm{~cd}$ & $3.04 \mathrm{~b}$ & $2.75 \mathrm{e}$ & $3.07 \mathrm{~d}$ & $3.38 \mathrm{c}$ & $3.28 \mathrm{~cd}$ & $3.12 \mathrm{~b}$ \\
\hline+ Rhizobium & $3.41 \mathrm{bc}$ & $3.49 \mathrm{ab}$ & $3.72 \mathrm{a}$ & $3.69 \mathrm{a}$ & $3.58 \mathrm{a}$ & $3.52 \mathrm{bc}$ & $3.65 \mathrm{ab}$ & $3.75 \mathrm{ab}$ & $3.86 \mathrm{a}$ & $3.69 \mathrm{a}$ \\
\hline Mean & $3.07 \mathrm{c}$ & $3.25 \mathrm{~b}$ & $3.47 \mathrm{a}$ & $3.45 \mathrm{a}$ & & $3.13 \mathrm{c}$ & $3.36 \mathrm{~b}$ & $3.56 \mathrm{a}$ & $3.57 \mathrm{a}$ & \\
\hline \multicolumn{11}{|c|}{ Phosphorus } \\
\hline - Rhizobium & $0.25 \mathrm{~d}$ & $0.29 \mathrm{c}$ & $0.31 \mathrm{c}$ & $0.31 \mathrm{c}$ & $0.29 \mathrm{~b}$ & $0.28 \mathrm{e}$ & $0.30 \mathrm{~d}$ & $0.31 \mathrm{~d}$ & $0.32 \mathrm{~d}$ & $0.30 \mathrm{~b}$ \\
\hline +Rhizobium & $0.34 \mathrm{~b}$ & $0.34 \mathrm{~b}$ & $0.36 \mathrm{ab}$ & $0.36 \mathrm{a}$ & $0.35 \mathrm{a}$ & $0.34 \mathrm{c}$ & $0.35 \mathrm{bc}$ & $0.37 \mathrm{ab}$ & $0.38 \mathrm{a}$ & $0.36 \mathrm{a}$ \\
\hline Mean & $0.29 \mathrm{c}$ & $0.32 \mathrm{~b}$ & $0.33 \mathrm{a}$ & $0.34 \mathrm{a}$ & & $0.31 \mathrm{c}$ & $0.33 \mathrm{~b}$ & $0.34 \mathrm{ab}$ & $0.35 \mathrm{a}$ & \\
\hline \multicolumn{11}{|c|}{ Potassium } \\
\hline - Rhizobium & $1.91 \mathrm{~d}$ & $2.18 \mathrm{~cd}$ & $2.29 \mathrm{c}$ & $2.25 \mathrm{c}$ & $2.16 \mathrm{~b}$ & $2.10 \mathrm{f}$ & $2.37 \mathrm{e}$ & $2.40 \mathrm{de}$ & $2.40 \mathrm{de}$ & $2.32 \mathrm{~b}$ \\
\hline+ Rhizobium & $2.45 \mathrm{bc}$ & $2.66 \mathrm{ab}$ & $2.80 \mathrm{a}$ & $2.87 \mathrm{a}$ & $2.69 \mathrm{a}$ & $2.63 \mathrm{~cd}$ & $2.79 \mathrm{bc}$ & $3.07 \mathrm{a}$ & $2.99 \mathrm{ab}$ & $2.87 \mathrm{a}$ \\
\hline Mean & $2.18 \mathrm{~b}$ & $2.42 \mathrm{a}$ & $2.54 \mathrm{a}$ & $2.56 \mathrm{a}$ & & $2.36 \mathrm{~b}$ & $2.58 \mathrm{a}$ & $2.73 \mathrm{a}$ & $2.70 \mathrm{a}$ & \\
\hline \multicolumn{11}{|c|}{ Crude protein } \\
\hline - Rhizobium & $17.06 \mathrm{e}$ & $18.78 \mathrm{~d}$ & $20.21 \mathrm{~cd}$ & $20.12 \mathrm{~cd}$ & $19.04 \mathrm{~b}$ & $17.19 \mathrm{e}$ & $19.18 \mathrm{~d}$ & $21.12 \mathrm{c}$ & $20.50 \mathrm{~cd}$ & $19.50 \mathrm{~b}$ \\
\hline +Rhizobium & $21.31 \mathrm{bc}$ & $21.84 \mathrm{ab}$ & $23.25 \mathrm{a}$ & $23.09 \mathrm{a}$ & $22.37 \mathrm{a}$ & $22.00 \mathrm{bc}$ & $22.84 \mathrm{ab}$ & $23.43 \mathrm{ab}$ & $24.12 \mathrm{a}$ & $23.10 \mathrm{a}$ \\
\hline Mean & $19.18 \mathrm{c}$ & $20.31 \mathrm{~b}$ & $21.73 \mathrm{a}$ & $21.61 \mathrm{a}$ & & $19.59 \mathrm{c}$ & $21.01 \mathrm{~b}$ & $22.28 \mathrm{a}$ & $22.31 \mathrm{a}$ & \\
\hline
\end{tabular}

Values followed by same letters within a column not significantly differed at $5 \%$ according to Duncan's multiple range test. SA: Salicylic acid at $250 \mathrm{mg} / \mathrm{L}$. and AA: Ascorbic acid at $250 \mathrm{mg} / \mathrm{L}$.

Table 9. Total carbohydrates, ascorbic and salicylic acids \% of pea seeds as affected by Rhizobium, antioxidants and their interactions during 2015/2016 and 2016/2017 growing seasons.

\begin{tabular}{|c|c|c|c|c|c|c|c|c|c|c|}
\hline \multirow[b]{2}{*}{ Treatments } & \multicolumn{5}{|c|}{$2015 / 2016$} & \multicolumn{5}{|c|}{$2016 / 2017$} \\
\hline & Control & SA & AA & $\begin{array}{c}\text { SA } \\
+ \\
\text { AA }\end{array}$ & Mean & Control & SA & AA & $\begin{array}{c}\text { SA } \\
+ \\
\text { AA }\end{array}$ & Mean \\
\hline \multicolumn{11}{|c|}{ Total carbohydrates } \\
\hline - Rhizobium & $45.05 \mathrm{e}$ & $48.16 \mathrm{~d}$ & $49.19 \mathrm{~cd}$ & $49.02 \mathrm{~cd}$ & $47.85 \mathrm{~b}$ & $46.24 \mathrm{~d}$ & $48.34 \mathrm{~cd}$ & $50.07 \mathrm{bc}$ & $49.31 \mathrm{bc}$ & $48.49 \mathrm{a}$ \\
\hline+ Rhizobium & $50.24 \mathrm{bc}$ & $50.99 \mathrm{ab}$ & $52.02 \mathrm{a}$ & $51.99 \mathrm{a}$ & $51.31 \mathrm{a}$ & $50.28 \mathrm{bc}$ & $51.32 \mathrm{ab}$ & $52.68 \mathrm{a}$ & $52.83 \mathrm{a}$ & $51.78 \mathrm{a}$ \\
\hline Mean & $47.64 \mathrm{~b}$ & $49.57 \mathrm{a}$ & $50.60 \mathrm{a}$ & $50.50 \mathrm{a}$ & & $48.26 \mathrm{~b}$ & $49.83 \mathrm{ab}$ & $51.37 \mathrm{a}$ & $51.07 \mathrm{a}$ & \\
\hline \multicolumn{11}{|c|}{ Ascorbic acid } \\
\hline - Rhizobium & $3.46 \mathrm{e}$ & $6.31 \mathrm{~d}$ & $8.04 \mathrm{c}$ & $8.99 \mathrm{~b}$ & $6.70 \mathrm{~b}$ & $4.82 \mathrm{~d}$ & $7.75 \mathrm{c}$ & $10.68 \mathrm{~b}$ & $10.46 \mathrm{~b}$ & $8.42 \mathrm{~b}$ \\
\hline+ Rhizobium & $3.50 \mathrm{e}$ & $6.39 \mathrm{~d}$ & $11.05 \mathrm{a}$ & $10.85 \mathrm{a}$ & $7.95 \mathrm{a}$ & $5.01 \mathrm{~d}$ & $7.83 \mathrm{c}$ & $12.28 \mathrm{a}$ & $12.20 \mathrm{a}$ & $9.33 \mathrm{a}$ \\
\hline Mean & $3.48 \mathrm{~d}$ & $6.35 \mathrm{c}$ & $9.55 \mathrm{~b}$ & $9.92 \mathrm{a}$ & & $4.91 \mathrm{c}$ & $7.79 \mathrm{~b}$ & $11.48 \mathrm{a}$ & $11.33 \mathrm{a}$ & \\
\hline \multicolumn{11}{|c|}{ Salicylic acid } \\
\hline - Rhizobium & $9.38 \mathrm{~d}$ & $13.97 \mathrm{~b}$ & $12.21 \mathrm{c}$ & $13.98 \mathrm{~b}$ & $12.38 \mathrm{~b}$ & $10.87 \mathrm{~d}$ & $15.31 \mathrm{~b}$ & $12.57 \mathrm{c}$ & $15.45 \mathrm{~b}$ & $13.55 \mathrm{~b}$ \\
\hline+ Rhizobium & $9.40 \mathrm{~d}$ & $16.85 \mathrm{a}$ & $12.30 \mathrm{c}$ & $16.78 \mathrm{a}$ & $13.83 \mathrm{a}$ & $10.88 \mathrm{~d}$ & $18.16 \mathrm{a}$ & $12.71 \mathrm{c}$ & $18.25 \mathrm{a}$ & $15.00 \mathrm{a}$ \\
\hline Mean & $9.39 \mathrm{c}$ & $15.41 \mathrm{a}$ & $12.25 \mathrm{~b}$ & $15.38 \mathrm{a}$ & & $10.87 \mathrm{c}$ & $16.73 \mathrm{a}$ & $12.64 \mathrm{~b}$ & $16.85 \mathrm{a}$ & \\
\hline
\end{tabular}

Values followed by same letters within a column not significantly differed at 5\% according to Duncan's multiple range test. SA: Salicylic acid at $250 \mathrm{mg} / \mathrm{L}$. and AA: Ascorbic acid at $250 \mathrm{mg} / \mathrm{L}$.

\section{Conclusion}

Results obtained in the present study confirmed that inoculation pea (Pisum sativum L.) seeds with Rhizobium, foliar spray with antioxidants i.e., salicylic acid (SA), ascorbic acid (AA) and SA+AA at $250 \mathrm{mg} \mathrm{L}^{-1}$ of each as well as their interactions were able to produce positive effects in pea plant. In particular, improving fresh and dry biomasses, photosynthetic pigment contents, yield components as well as seed bioconstituents have been observed due to treatments application under salinity conditions. Consequently, supply of inoculation pea seeds with Rhizobium along with foliar spray of $\mathrm{SA}+\mathrm{AA}$ was the most effective treatment on alleviating the negative effects of saline stress. 
References

A.O.A.C. Association of Official Analytical Chemists 2000. Official Methods of Analysis. $17^{\text {th }}$ ed. A.O.A.C. International Maryland, USA, 1250.

Aamir, M.; Aslam, A.; Khan, M. Y.; Jamshaid, M. U.; Ahmad, M.; Asghar, H. N. and Zahir, Z. A. 2013. Co-inoculation with Rhizobium and plant growth promoting rhizobacteria (PGPR) for inducing salinity tolerance in mung bean under field condition of semi-arid climate. Asian $\mathrm{J}$ Agric Biol., 1(1):17 - 22.

Abdel-Halim, S. M. 1995. Effect of some vitamins as growth regulators on growth, yield and endogenous hormones of tomato plants during winter. Egypt. J. Appl. Sci., 10(12): 322 - 334.

Abdel-Hameed, A. M.; Sarhan, S. H. and AbdelSalam, H. Z. 2004. Evaluation of some organic acid as foliar application on growth, yield and some nutrient contents of wheat. J. Agric. Sci. Mansoura Univ., 20(5): 2476 - 2481.

Abou El-Salehein, E. H.; Wahdan, H. I.; EIHamady, M. M. and Baddour, G. A. 2005. Effect of some biostimulants and NPK fertilizers levels on growth, green pod yield and its quality of peas. J. Agric. Sci. Mansoura Univ., 30(2): $1055-1067$.

Aftab, T.; Khan, M. M. A.; Idrees, M.; Naeem, M. and Moinuddin 2010. Salicylic acid acts as potent enhancer of growth, photosynthesis and artemisinin production in Artemisia annua L. J. Crop Sci. and Biotech., 13: 183 -188.

Ahmed, R.; Solaiman, A. R. M.; Halder, N. K.; Siddiky, M. A. and Islam, M. S. 2007. Effect of Inoculation Methods of Rhizobium on Yield Attributes, Yield and Protein Content in Seed of Pea. J. Soil. Nature, 1(3): 30 - 35.

Ahmed, S. 2009. Effect of soil salinity on the yield and yield components of mungbean. Pak. J. Bot., 1: 263 - 268

Al-Hakimi, A. M. A. and Hamada, A. M. 2001. Counteraction of salinity stress on wheat plants by grain soaking in ascorbic acid, thiamine or sodium salicylate. Biol. Plant., 44: 253 - 261.

Ali, S. F.; Rawat, L. S.; Meghvansi, M. K. and Mahna, S. K. 2009. Selection of stress-tolerant rhizobial isolates of wild legumes growing in dry regions of Rajasthan, India. Arpn. J. Agric. Biol. Sci., 4:13 - 18 .

Alqurainy, F. 2007. Responses of bean and pea to vitamin $\mathrm{C}$ under salinity stress. Res. J. Agric. Biol. Sci., 3: 714 - 722.

Arberg, B. 1981. Plant growth regulators. Monosubstituted benzoic acid. Swed. Agric. Res., 11: $93-105$.

Athara, H.; Khanb, A. and Ashraf, M. 2008. Exogenously applied ascorbic acid alleviates saltinduced oxidative stress in wheat. Env. Exp. Bot., 63: $224-231$.
Bambara, S. and Ndakidemi, P. A. 2009. Effects of Rhizobium inoculation, lime and molybdenum on photosynthesis and chlorophyll content of Phaseolus vulgaris L. Afr. J. Microbiol. Res., 3(11): 791 - 798.

Barakat, M. A. S.; Osman, A. S.; Semida, W. M. and Gyushi, M. A. H. 2015. Influence of potassium humate and ascorbic acid on growth, yield and chemical composition of common bean (Phaseolus vulgaris L.) grown under reclaimed soil conditions. Int. J. Acad. Res., 7(1): 192 - 199.

Benidire, L.; Lahrouni, M.; El Khalloufi, F.; Göttfert, M. and Oufdou, K. 2017. Effects of Rhizobium leguminosarum Inoculation on Growth, Nitrogen Uptake and Mineral Assimilation in Vicia faba Plants under Salinity Stress. J. Agric. Sci. Tech., 19: 889 - 901.

Black, C. A. 1965. Methods of Soil Analysis. Part 2. Chemical and Microbiological Properties. Amer. Soci. Agron., Madison, Wisconsin, USA.

Bolkhina, O.; Virolainen, E. and Fagerstedt, K. 2003. Antioxidant, oxidative damage and oxygen deprivations stress. A review. Ann. Bot., 91: 179 - 194.

Borsani, O.; Valpuesta, V. and Botella, M. A. 2001. Evidence for a role of salicylic acid in the oxidative damage generated by $\mathrm{NaCl}$ and osmotic stress in Arabidopsis seedlings. Plant Physiol., 126: 1024 - 1030.

Buxton, G.; Geyre, B. and Huyskens-Keil, S. 2002. Effects of ascorbic acid, charcoal, glucose, and salicylic acid in nutrient solutions on vegetative growth and the susceptibility of Phaseolus vulgaris to sodium chloride. Ghana J. Agric. Sci., 35: 129 - 141.

Chame, S. K.; Khalil-Tahmasbi, B.; ShahMahmoodi, P.; Abdollahi, A.; Fathi, A.; Mousavi, S. J. S.; Abadi, M. H.; Ghoreishi, S. and Bahamin, S. 2016. Effects of salinity stress, salicylic acid and Pseudomonas on the physiological characteristics and yield of seed beans (Phaseolus vulgaris). Sci. Agric., 14(2): 234 - 238.

Chapman, H. D. and Pratt, P. F. 1982. Methods of analysis for soils, plants and water. Chapman Publisher, Riverside, CA.

Chen, Z. and Gallie, D. R. 2006. Dehydro ascorbate reductase affects leaf growth development and function. Plant Physiol., 142(2): 775 - 787.

Conklin, P. 2001. Recent advances in the role and biosynthesis of ascorbic acid in plants. Plant Cell Environ., 24: 383 - 394.

Dhanavel, D. and Girija, M. 2009. Effect of EMS; DES and SA on quantitative traits of cowpea (Vigna unguiculata L. Walp.) in M1 generation. Crop Research (Hisar), 37(1/3): 239 - 241.

Dolatabadian, A. and Jouneghani, R. S. 2009. Impact of exogenous ascorbic acid on antioxidant activity and some physiological traits of common 
bean subjected to salinity stress. Not. Bot. Hort. Agrobot. Cluj., 37(2): 165 - 172.

Duncan, D. B. 1958. Multiple ranges and multiple F test. Biometrics, 11: $1-42$.

Ebrahim, M. K. 2005. 'Amelioration of sucrosemetabolism and yield changes, in storage roots of $\mathrm{NaCl}$-stressed sugarbeet, by ascorbic acid'. Agrochimica, XLIX (3 - 4): 93 - 103.

El Sayed, Hameda E. A.; Amen, El-Sh. A.; EIMorsy, A. H. and Tolba, M. H. 2012. Effects of foliar spraying with microelements and different fertilizer sources on quality and yield of Pisum sativum L. plant. Int. Res. J. Agric. Sci. Soil Sci., 2(1): 017 - 024.

El-Bassiouny, H. M. S.; Gobarah, M. E. and Ramadan, A. A. 2005. Effect of antioxidants on growth, yield and favisum causative agents in seeds of Vicia faba L. plants grown under reclaimed sandy soil. J. Agron., 4(4): 281 - 287.

El-Hamdaoui, A.; Redondo-Nieto, M.; Rivilla, R.; Bonilla, I. and Bolanos, L. 2003. Effects of boron and calcium nutrition on the establishment of the Rhizobium leguminosarum-pea (Pisum sativum L.) symbiosis and nodule development under salt stress. Plant Cell Environ., 26(7): 1003 $-1011$.

El-Hendaway, S.; Shaban, W. and Sakagami, J. I. 2011. Does treating faba bean seeds with chemical inducers simultaneously increase chocolate spot disease resistance and yield under field conditions. Turkish J. Agric. Forest., 34(6): $475-485$.

El-Sheikh, E. A. and Osman, A. G. 2002. Allevation of salinity and viral diseases effect on faba bean by inoculation and nitrogen fixation. Inviron. Nat. Reso. Res. Inst., 8(1): 73 - 83.

El-Shraiy, A. M. and Hegazi, A. M. 2009. Effect of Acetylsalicylic Acid, Indole-3-Bytric Acid and Gibberellic Acid on Plant Growth and Yield of Pea (Pisum Sativum L.). Aust. J. Basic \& Appl. Sci., 3(4): 3514 - 3523.

Fahad, S. and Bano, A. 2012. Effect of salicylic acid on physiological and biochemical characterization of maize grown in saline area. Pak. J. Bot., 44(4): 1433 - 1438.

Fahad, S.; Hussain, S.; Bano, A.; Saud, S.; Hassan, S.; Shan, D.; Khan, F. A.; Khan, F.; Chen, Y.; Wu, C.; Tabassum, M. A.; Chun, M. X.; Afzal, M.; Jan, A.; Jan, M. T. and Huang, J. 2014. Potential role of phytohormones and plant growth-promoting rhizobacteria in abiotic stresses: consequences for changing environment. Environ. Sci. Poll. Res., doi: 10.1007/s11356014-3754-2.

Farooq, M.; Basra, S. M. A.; Tauseef, M.; Rehman, H. and Munir, H. 2007. Priming with ethanol ascorbate and salicylicate enhance the germination and early seedling growth of pea (Pisum sativum L.). Pak. J. Agric. Sci., 44(1): 30 - 39.
Gaballah, M. S. and Gomaa, A. M. 2005. Interactive Effect of Rhizobium Inoculation, Sodium Benzoate and Salinity on Performance and Oxidative Stress in Two Fababean Varieties. Int. J. Agric. Biol., 7(3): 495 - 498.

Gabr, S. M.; Elkhatib, H. A. and El-keriawy, A. M. 2007. Effect of different biofertilizer types and nitrogen fertilizer levels on growth, yield and chemical contents of pea plants (Pisum sativum L.). J. Agric. \& Env. Sci. Alex. Univ., Egypt, 6(2): 192 - 218.

Gabriela, M. Pastori; Kiddle, G.; Antoniw, J.; Bernard, S.; Veljovic-Jovanovic, S.; Paul; Noctor, J. V. G. and Foyer, C. H. 2003. Leaf vitamin $\mathrm{C}$ contents modulate plant defense transcripts and regulate genes that control development through hormone signaling. The Plant Cell, 15(4): 939 - 951.

Gad El-Hak, S. H.; Ahmed, A. M. and Moustafa, Y. M. M. 2012. Effect of foliar application with two antioxidants and humic acid on growth, yield and yield components of peas (Pisum sativum L.). J. Hort. Sci. \& Ornamen. Plants, 4(3): 318 - 328.

Gahalain, A.; Kumar, P.; Bhatt, J. C.; Dubes, S. D. and Chauhan, V. S. 1999. Effect of environmental conditions, salicylic acid and phytohormones on pea leaf blight. Indian Phytopath., 52(3): 270 - 273.

Ghorbani, M.; Ebrahimzadeh, H. and Sharifi, M. 2004. Effects of $\mathrm{NaCl}$ and mycorrhizal fungi on antioxidative enzymes in soybean. Biol. Plant., 48(4): 575-581.

Ghulam, M.; Rehana, A.; Shabbaz, S. A. and Majid, A. 2007. The yield and components of pea (Pisum sativum L.) as influenced by salicylic acid. Pak. J. Bot., 39(2): 551- 559.

Glenn, E. P.; Brown, J. J. and Blumwald, E. 1999. Salt tolerance and crop potential of halophytes. Crit. Rev. Plant Sci., 18(2): 227 - 255.

Gunes, A.; Inal, A.; Alpaslan, M.; Eraslan, F.; Bagci, E. G. and Cicek, N. 2007. Salicylic acid induced changes on some physiological parameters symptomatic for oxidative stress and mineral nutrition in maize (Zea mays L.) grown under salinity. J. Plant Physiol., 164(6): 728 736.

Hadi, H.; Najafabadi, A. and Amirnia, R. 2014. Comparison of different treatment methods of salicylic acid on some physiological traits of white bean under salinity stress. Cercetari Agronomice in Moldova, 47(3): 97 - 105.

Haroun, S. A.; Aldesuqy, H. S.; Shukry, W. M. and Gaber, A. M. 1998. Regulation of growth and metabolism in Lupinus termis plant by sodium salicylate. Egypt. J. physiol. Sci., 22: 75 95.

Hayat, Q.; Hayat, S.; Irfan, M. and Ahmad, A. 2010. Effect of exogenous salicylic acid under changing environment: A review. Env. Exp. Bot., 68(1): 14 - 25 . 
Hayat, S. and Ahmad, A. 2007. Salicylic Acid: A Plant Hormone. Springer, Dordrecht, The Netherlands, pp: 1 - 14.

Helal, F. A; Farag, S. T. and El-Sayed, S. A. 2005. Studies on growth, yield and its components and chemical composition under effect of vitamin $\mathrm{C}$, vitamin B1, boric acid and sulphur on pea (Pisum sativum L.) plants. J. Agric. Sci. Mansoura Univ., 30(6): 3343 - 3353.

Hussein, M. M.; El-Gereadly, N. H. M. and ElDesuki, M. 2006. Role of puterscine in resistance to salinity of pea plants (Pisum Sativum L.). J. of Appl. Sci. Res., 2(9): 598 - 604.

Iqbal, N.; Umar, S.; Khan, N. A. and Khan, M. I. R. 2014. A new perspective of phytohormones in salinity tolerance: regulation of praline metabolism. Environ. Exp. Bot., 100: 34 - 42.

Irfan, A.; Basra, S. M. A.; Mahammed, F. and Nawaz, A. 2006. Alleviation of salinity stress in spring wheat by hormonal priming with ABA, Salicylic acid and ascorbic acid. Int. J. Agric. Biol., 8(1): 23 - 28.

Ismaeil, F. H. M. and Abd El-All, M. M. 2011. Effect of some growth regulators and antioxidants on growth, yield and seed chemical composition of faba bean plants. J. Plant Production, Mansoura Univ., 2(11): 1563 - 1577.

Jagnow, G.; Hoflich, G. and Haffmann, K. H. 1991. Inoculation of non-symbiotic rhizosphere bacteria: Possibilities of increasing and stabilizing yields. Angew. Botanik, 65: 97 - 126.

Jamil, M.; Rehman, S.; Kui, J. L.; Kim, J. M.; Kim, H. S. and Rha, E. S. 2007. Salinity reduced growth Ps2 photochemistry and chlorophyll content in radish. Sci. Agric. (Piracicaba, Braz.), 64(2): 111 - 118.

Jones, I. R.; Benton, I.; Wolf, B. and Mills, H. A. 1991. Plant analysis. Handbook, Methods of plant analysis and inter-predation. Micro-Macro. Publishing, Inc., USA, pp: 30 - 34.

Kamalendu, C. and Srivastava, R. C. 2010. Phytoremediation of methionine, vitamin $\mathrm{C}$ and EDTA in combating the deleterious effects of $\mathrm{K}_{2} \mathrm{Cr}_{2} \mathrm{O}_{7}$ on biomass, in vivo nitrate reductase activity and soluble protein in Pisum sativum L. Vegetos, 23(2): 105 - 113.

Kent, M. B. S. and Endres, G. 2003. Field pea production. North Dakota State University, Fargo, North Dakota.

Khafaga, E. E. E.; Hasanin, S. A. and El-Shal, R. M. 2014. Effect of foliar application with ascorbic, humic acids and compost tea on nutrients content and faba bean productivity under sandy soil conditions. J. Soil Sci. and Agric. Eng., Mansoura Univ., 5(6): 767 - 778.

Khan, W.; Prithiviraj, B. and Smith, D. 2003. Photosynthetic response of corn and soybean to foliar application of salicylates. J. Plant Physiol., 160(5): 485 - 492.
Kim, S. Y.; Lim, J. H.; Park, M. R.; Kim, Y. J.; Park, T. I.; Seo, Y. W.; Choi, K. G. and Yun, S. J. 2005. Enhanced antioxidant enzymes are associated with reduced hydrogen peroxide in barley roots under saline stress. J. Biochem. Mol. Biol., 38(2): 218 - 224.

Koller, H. R. 1972. Leaf area-leaf weight relationship in the soybean canopy. Crop Sci., 12: $180-183$.

Kumari, A.; Kumari, V. S. and Sheokand, S. S. 2008. Oxidative metabolism in $\mathrm{Cd}^{2+}$-treated pea leaves as affected by ascorbic acid and putrescine. Journal of plant Biology, 35: 181192.

Levy, Y. and Syvertsen, J. P. 2004. Irrigation water quality and salinity effects in citrus trees. Hort., Rev., 30: 37 - 82.

Marschner, H. 1995. Mineral Nutrition of Higher Plants. $2^{\text {nd }}$ ed. New York, USA: Academic Press, Harcourt Brace Jovanovich, Publisher, pp: 674.

Martin, P.; Glatzle, A.; Klob, W.; Omay, H. and Schmidt, W. 1989. N2-fixing bacteria in rhizosphere: Quantification and hormonal effects on root development. Z. Pflanzenernuhr Bodenk, 152: 237 - 245

Mayak, S.; Tirosh, T. and Glick, B. R. 2004. Plant growth-promoting bacteria confer resistance in tomato plants to salt stress. Plant Physiol. Biochem., 42: 565 - 572.

Mazumdar, B. C. and Majumder, K. 2003. Methods on physico-chemical analysis of fruits. Daya Publishing House, Delhi-110035, 93-95.

McKersie, B. D.; Bowley, S. R. and Jones, K. S. 1999. Winter survival of transgenic alfalfa clover expressing superoxide dismutase'. Plant Physiol., 119: 839 - 847 .

McKersie, B. D.; Bowley, S. R.; Harjanto, E. and Leprice, O. 1996. Water-deficit tolerance and field performance of transgenic alfalfa overexpressing superoxide dismutase. Plant Physiol., 111:1321- 1326.

Mishra, A.; Prasad, K. and Rai, G. 2010. Effect of bio-fertilizer inoculations on growth and yield of dwarf field pea (pisum sativum L.) in conjunction with different doses of chemical fertilizers. J. Agron., 9 (4): 163 - 168.

Mohsen, Awatif A.; Ebrahim, M. K. H. and Ghoraba, W. F. S. 2014. Response of saltstressed Vicia faba L. plant to application of ascorbic acid on the growth and some metabolites. I. J. of Plant Physiol., 4: 957 - 976.

Osman, E. A. M; M. A. El- Galad; K. A. Khatab and M. A. B. El-Sherif (2014): Effect of compost rates and foliar application of ascorbic acid on yield and nutritional status of sunflower plants irrigated with saline water. Glob. J. Sci. Res., 2 (6): 193 - 200.

Page, A. L.; Miller, R. H. and Keeney, D. R. 1982. Methods of Soil Analysis. Part 2. Chemical and 
Microbiological properties. Amer. Soc. Agron., Madison, Wisconsin, USA.

Palma, F.; Lluch, C. and Iribarne, C. 2009. Combined effect of salicylic acid and salinity on some antioxidant activities, oxidative stress and metabolite accumulation in Phaseolus vulgaris. Plant Growth Regul., 58:307-316.

Paranychianakis, N. V. and Chartzoulakis, K. S. 2005. Irrigation of mediterranean crops with saline water: from physiology to management practices. Agric. Ecosyst. Environ., 106: 171 187.

Pastori, G. M.; Kiddle, G.; Antoniw, J.; Bernard, S.; Veljovic-Jovanovic, S.; Verrier, P. J.; Noctor, G.and Foyer, C. H. 2003. Leaf vitamin $\mathrm{C}$ contents modulate plant defense transcripts and regulate genes that control development through hormone signaling. Plant Cell, 15: 939 -951.

Radi, A. F.; Ismail, A. M. and Azooz, M. M. 2001. Interactive effect of some vitamins and salinity on the rate of transpiration and growth of some broad bean lines'. Indian Plant-Physiol., 6(1): 24 29.

Rady, M. M. 2013. Inducing pea plants for conquering the adverse conditions of saline reclaimed soils with some support applications. In: Shbbir, A. S., Abd El-fattah, M. A. and Taha, F. K. (Eds.). Developments in Soil Salinity Assessment and Reclamation. International Conference, 17-19 May 2010, International Center for Biosaline Agric., Abu Dhabi, United Arab Emirates. Springer, 479 - 495.

Rady, M. M. and Mohamed, G. F. 2015. Modulation of salt stress effects on the growth, physio-chemical attributes and yields of Phaseolus vulgaris L. plants by the combined application of salicylic acid and Moringa oleifera leaf extract. Scientia Horticulturae 193: 105-113.

Rady, M. M.; Mohamed, G. F.; Abdalla, A. M. and Ahmed, Yasmin H. M. 2015. Integrated application of salicylic acid and Moringa oleifera leaf extract alleviates the salt-induced adverse effects in common bean plants. J. of Agric. Technol., 11(7): 1595 -1614.

Raskin, I. 1992. Salicylate, a new plant hormone. Plant Physiol., 99: 799 - 803.

Raskin, I. 1995. Salicylic acid plant hormones physiology. Biochem. Mol. Biol. New york USA., 188 - 205.

Rasmussen, J. B.; Hammerschmidt, R. and Zook, M. N. 1991. Systemic induction of salicylic acid accumulation in cucumber after inoculation with Pseudomonas syringae pv. Syringae. Plant Physiol., 97: 1342 - 1347.

Sajid, Z. A.; Safdar, M. and Khilji, S. A. 2016. Amelioration of salinity stress tolerance in pea (pisum sativum L.) by exogenous application of salicylic acid. BIOLOGIA, 62 (1): 69 - 78.

Sakr, M. T.; Abd El-Salam, Heba M.; Atta, Marouah I. and Abd-El-Aal, M. A. A. 2013.
Alleviating the harmful effect of salinity stress on soybean plants by using some promoters. J. Plant Production, Mansoura Univ., 4 (2): 205 - 218.

Salama, Zeinab A.; Abou El-Nour, El. A. A.; El Fouly, M. M. and Gaafar, Alaa A. 2014. Ascorbic acid foliar spray counteracting effect of salinity on growth, nutrients concentrations, photosynthesis, antioxidant activities and lipid peroxidation of bean (Phaseulus vulgaris L.) cultivars. Am. J. of Agric. and Biol. Sci., 9 (3): $384-393$.

Salinas, F.; Berzas, I. I. and Espinosa, A. 1990. A new spectro photometric method for quantitative multi component analysis resolution of mixtures of salicylic and salicyluric acids. Talanta, 37(3): $347-351$.

Sarang, Y.; Them, K. and Singh, T. H. N. 2003. Efficacy of salicylic acid on growth, nitrogen metabolism and flowering of Phaseolus vulgaris. Crop Res., 26: 355 - 360.

Shafeek, M. R.; S. A. Faten and H. A. Aisha 2004. The productivity of broad bean plant as affected by chemical and / or natural phosphorus with different biofertilizer. J. Agric. Sci. Mansoura Univ., 29(5): 2727-2740.

Shalata, A. and Neumann, M. 2001. Exogenous ascorbic acid (Vitamin C) increases resistance to salt stress and reduces lipid peroxidation'. Exp. Bot., 52(364): 2207-2211.

Shokr, M. M. B. and Abdelhamid, M. T. 2009. Using some antioxidant substances for enhancing thermotolerance and improving productivity of pea (Pisum sativum 1.) plants under local environment of early summer season. Agric. Res. J.Suez Canal Univ., 9 (1): 69 - 76.

Shrivastava, P. and Kumar, R. 2015. Soil Salinity: A Serious Environmental Issue and Plant Growth Promoting Bacteria as One of the Tools for Its Alleviation. Saudi J. Biol. Sci., 22: 123 - 131.

Singh, S. K.; Pancholy, A.; Jindal, S. K. and Pathak, R. 2011. Effect of plant growth promoting rhizobia on seed germination and seedling traits in Acacia Senegal. Ann. For. Res., 54: $161-169$.

Slatery, J. F., Coventry, D. R. and Slattery, W. J. 2001. Rhizobial ecology as affected by the soil environment. Aust. J. Exp. Agric., 41: 289 - 98.

Snedecor, G.W. and Cochran, W.G. 1980. Statistical Methods $7^{\text {th }}$ ed., Iowa State Univ.,Press. Ames., USA.

Sobh, M. M.; Genaidy, S. and Hegazy, M. 2000. Comparative studies on mineral and biofertilization for some main field crops in northern Delta soils. Zagazig J. Agric. Res., 27 (1):171 - 179.

Steppuhn, H., Volkmar, K. M. and Miller P. R. 2001. Comparing canola, field pea, dry bean, and durum wheat crops grown in saline media. Crop Sci., 41: 1827 - 1833. 
Sultana, P., Rai, K.; Ahmed, S. and Beg, M. Z. 2009. A study on impact of thiamine, pyridoxine, ascorbic acid on pisum sativum L. var. Aparna. J. of Living World, 16: 1-7.

Talaat, N. B. 2003. Physiological studies on the effect of salinity, ascorbic acid and putrescine of sweet pepper plant. Ph.D. Thesis, Fac. Agric.Cairo Univ., Egypt.

Tartoura, E. 2002. Growth and Yield of pea plants as affected by both biofertilizers and ATP. $2^{\text {nd }}$ inter. Conf. Hort. Sci., 10-12 Sept., Kafr El Sheikh, Tanta Univ. Egypt.

Timmerman-Vaughan, G. M.; Mills, A.; Whitfield, C.; Frew, T.; Butler, R.; Murray, S.; Lakeman, M.; McCallum, J.; Russell, A. and Wilson, D. 2005. Linkage mapping of QTL for seed yield, yield components, and developmental traits in pea. Crop Sci., 45: 1336 44.

Tiwari, S.; Chauhan, R. K.; Singh, R.; Shukla, R. and Gaur, R. 2017. Integrated Effect of Rhizobium and Azotobacter Cultures on the Leguminous Crop Black Gram (Vigna mungo). Adv. Crop Sci. Tech., 5(3) 1000289.

Trachevsky,I. A.; Yakovelva, V.G. and Egorova, A. 2011. Effects of salicylic acid on protein content and ${ }^{14} \mathrm{c}$ amino acid incorporation in to proteins of pea roots. Russ. J. of Plant Physiol., 58(4): 580 - 588.

Ullah, M. A.; Baber, R.; Hyder, S. I.; Sultan, T.; Mahmood, I. A. and Ullah, K. 2016. Effect of Rhizobium on Growth of Different Mungbean Varieties Under Salt Stress Conditions.
Landmark Res. J. Agric. Soil Sci., 3 (3): 018 021.

Vessey, J. K. 2003. Plant growth promoting rhizobacteria as biofertilizers. Plant Soil, 255: $571-586$.

Wettstein, D. 1957. Chlorophyll, Letal and dersubmicro-Spische Formmech Sellderplastideu, Exp.Cell Res., 12: 427.

Wolucka, B. A.; Goossens, A. and Inze, D. 2005. Methyl jasmonate stimulates the de novo biosynthesis of vitamin $\mathrm{C}$ in plant cell suspensions. J. Exp. Botany, 56: 2527 - 2538.

Yadav, P. K.; Raj, G. S.; Nirbhay, B. and Chaturvedi, S. 2008. Effect of bioregulators on growth and grain yield in field pea. J. of food legume., 21: 206 - 207.

Yildirim, E.; Taylor, A. G. and Spittler, T. D. 2006. Ameliorative effects of biological treatments on growth of squash plants under salt stress. Sci. Hortic., 111:1 - 6.

Zahran, H. H. 1999. Rhizobium-legume symbiosis and nitrogen fixation under severe conditions and in arid climate. Microbiol. Mol. Biol. Rev., 63: 968 - 989.

Zaki, R. N. and Radwan, T. E. E. 2011. Improving Wheat Grain Yield and Its Quality under Salinity Conditions at a Newly Reclaimed Soil by Using Different Organic Sources as Soil or Foliar Applications. J. Appl. Sci. Res., 7(1): 42 - 55.

Zewail, Y. M. R. 2007. Improvement of wheat productivity by using some biofertilizers and antioxdants'. M.Sc. Thesis, Fac. Agric. Moshtohor ,Banha Univ. 


\section{تأثير التلقيح بالريزوييم والرش الورقى بأحماض الساليسيلك والإسكوريك على النمو والمحصول وجودة البذور في نبات البسلة المنزرع فى أرض متأثرة بالملوحة ، الوادى الجديد - مصر \\ عصمت حسن نوفل 1 و محمد احمد محمد على 2 و محمد محمد محمود عبد العال 3

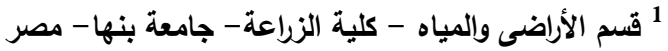

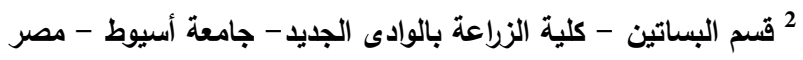

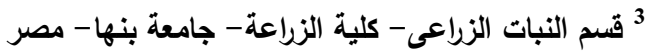

أجريت هذه الدراسة بهدف دراسة تأثير معاملة البذور بالتسميد الحيوى (الريزوبيم) والرش الورقى بمضادات الأكسدة (حامض الساليسيلك

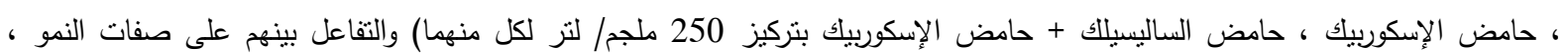
المحصول ومكوناته والمكونات الكيميائية للبذور في نبات البسلة صنف ماستر بى المنزرع فى أرض منأثرة بالملوحة ، الوادى الجديد - مصر خلاد موسمى الزراعة 2016/2015 و 2017/2016 لتعظيم الإنتاجية تحت ظروف الإجهاد الملحى. بالنسبة للمعاملة بالريزوبيم تم تلقيح البذور قبل الزراعة بالبكتريا المنبتة للنيتروجين (الريزوبيم) بينما تم الرش الورقى بمعاملات مضادات الأكسدة بعد 20 يوم من الزراعة مع التكرار 3 مرات بفاصل زمنى 10 أيام خلال موسمى النمو. سجلت القياسات الأتية خلال فترة النمو وعند الحصاد: صفات النمو الخضرى ، عدد العقد الجذرية ، الوزن الطازج والجاف للعقدة الجذرية ، محتوى الأوراق من صبغات البناء الضوئى ، المحصول الطازج والجاف ومكوناته بالإضافة إلى المكونات الكيمبائية للبذور .

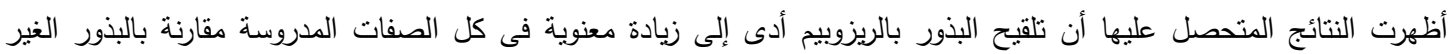
معاملة بالريزوبيم (الكنترول). أدى الرش الورقى للنبات بمعاملات مضادات الأكسدة (حامض الساليسيلك وحامض الإسكوربيك بتركيز 250 ملجم/ لتز لكل منهما

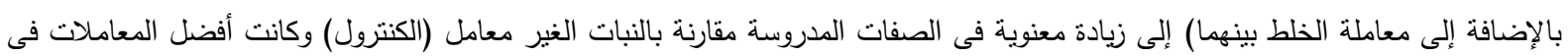
هذا الصدد التداخل بين الساليسيلك والإسكوربيك بتركيز 250 ملجم/ لتر لكل منهما. أدت معاملات التفاعل بين تلقيح البذور بالريزوبيم والرش الورقى بمضادات الأكسدة (حامض الساليسيلك وحامض الإسكوربيك بتركيز

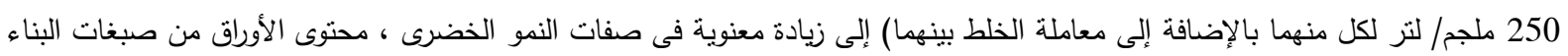
الضوئى ، عدد ووزن العقد البكتيرية ، المحصول الطازج والجاف ومكوناته ، محتوى البذرة من النيتروجين ، القوسفور ، البوتاسيوم ، البروتين

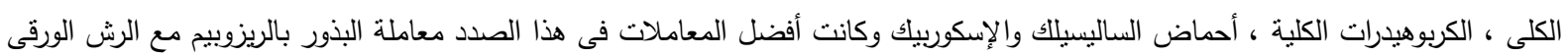
بحامض الساليسيلك وحامض الإسكوربيك معاً مقارنة بالمعاملات الأخرى. 